\title{
Relief and changes in the vegetation cover and the flora of the Zadroże Dune near the city of Torun: Comparison of the conditions in 1948 and 2009
}

\author{
*Andrzej Nienartowicz, **Mieczysław Kunz, ***Edyta Adamska, ***Urszula Boińska, \\ *Miłosz Deptuła, ***Wanda Gugnacka-Fiedor, ***Dariusz Kamiński, ***Lucjan Rutkowski \\ * Laboratory of Ecological Processes Modelling, Institute of Ecology and Environment Protection, \\ ** Department of Cartography, Remote Sensing and GIS, Institute of Geography, \\ *** Department of Taxonomy and Plant Geography, Institute of Ecology and Environment Protection, \\ Faculty of Biology and Earth Sciences, Nicolaus Copernicus University, \\ Gagarina 9, 87-100 Torun, Poland \\ e-mail: anienart@umk.pl
}

\begin{abstract}
The relief of the Zadroże Dune was described, as well as the comparison was done on its vegetation cover and the flora in its two phases of the development, i.e. before the afforestation of the dune and approximately 60 years after reconstruction of the forest. The first state was described in the paper dated 1949. During that period the dune constituted the first common study area for the research team consisting of ecologists and geographers from the Nicolaus Copernicus University. Our contemporary scientific studies were carried out in 2009. In the comparative analysis, a particular attention was paid to the distribution, the number and the size of heath patches with Arctostaphylos uva-ursi. In the description of the contemporary state of vegetation, the structure and the biomass of tree stands were included. The GIS and GPS technologies were applied in the comparative analysis of the vegetation, in the comparison of the former and contemporary cartographic materials, aerial and satellite images, as well as in the development of a digital elevation model. As a result of comparisons of the vegetation cover, it was found that the surface area of heaths decreased from 59.21 ares in 1948 to 2.96 ares in 2009. As a result of comparisons of the flora, it was found that 7 and 26 species of lichens occurred in 1948 and 2009 respectively, 5 and 42 species of mosses, 0 and 7 species of liverworts, as well as 102 and 204 species of vascular plants. The number of families, within which the species of vascular plants are classified, increased from 31 to 52 . The compared floras have only 66 species in common. The percentage contribution of geographical and historical groups has undergone only inconsiderable changes during the 60 -year period. Contribution proportions of non-synanthropic spontaneophytes and apophytes has changed slightly. Whereas, the contribution of alien species, mainly kenophytes and ergasiophytes significantly increased. This paper discuss the significance of natural and anthropogenic factors, which brought about this considerable range of transformations in the species composition and in the contribution of alien species.
\end{abstract}

Key words: afforestation, DEM, flora, GIS, GPS, heaths, IKONOS, indices of flora synanthropization, inland dunes, psammophilous grasslands, species richness, Toruń Valley, tree stand.

\section{Introduction}

In Poland three dune areas occur, perhaps the most classic dunes in Europe. According to Jadwiga Kobendza and Roman Kobendza (1958), the following areas should be included within the aforementioned areas: the ice-marginal valley of the Warta River, the Torun Valley and the junction near Warsaw between the ice-marginal Valley of the Vistula River, the Bug River and the Narwia River. Galon (1958) includes the Kurpie Forest among the most interesting, the largest and typically developed dune landscapes in Poland, obviously apart from the above-mentioned areas 
defined by him as dune units of the Warta - Noteć Interfluve, the Torun-Bydgoszcz Valley and the Warsaw Valley. Nowadays, most of the dunes in these four aforementioned regions are covered by forests, which are the state property. Forest vegetation, existing as Noteć Forest, ToruńBydgoszcz Forest, Kampinos Forest and Kurpie Forest, as well as the layer of forest soil, which was accumulated here ages ago, consolidated huge masses of sand deposited in ice-marginal valleys. In many places, the forest cover have been destroyed and transformed as a consequence of intentional or unintentional human activity. In places where vegetation of the forest floor and the humus layer were preserved, heaths or xerothermic meadows developed soon, which were then gradually overtaken by self-seeding pine. In places where destructive human activity initiated the process of shifting dunes, extensive areas of quicksand developed. Certain species of mosses, lichens and especially grasses were of particular significance for the stabilization of dunes. By encroaching on the area, they contributed to the development of psammophilous grasslands.

In the forest areas, the forest logging was the cause of transformation of forest into non-forest vegetation, including heathlands. The logging was particularly intensive during the 2nd World War and during the post-war period, followed by subsequent difficulties with forest regeneration in sandy areas, as well as frequent fires within extensive pine monocultures. When presenting the conditions of dune areas in the Warsaw Valley in the mid-20th century, J. and R. Kobendza (1958) wrote that dune areas, which are private property for years, already long time ago had been largely deprived of forest vegetation, and since then have been exploited as grazing lands and partly as arable fields. As a consequence of intensive management, the process of destruction of the existing dune forms has begun in many places of the Kampinos Forest; few miniature deserts developed awaiting the afforestation.

Whereas in the Torun Valley, the military activity was the factor transforming the forest vegetation into heathlands and psammophilous grasslands. This military activity consisted in construction of fortifications, as well as the development and maintenance of training grounds and military warehouses. Construction and maintenance of such facilities was possible in the past due to the PrussianRussian border running near the city of Torun.

Galon (1958) states that as opposed to dunes in the Netherlands and Germany, the dunes in Poland represent a more continental variant. Consequently, controlling the aeolian processes is more difficult in Poland than in western Europe. And thus the development and management of dunes has become an important economic and technical issue, which requires a thorough knowledge of eolian processes and monographs on all dune areas in Poland. During the last 60 years, apart from the afforestation performed by State Forests, also the natural succession proc- esses contributed to the stabilization of wind-blown dunes. They brought about the increase of the vegetation area, as well as the complication of the structure of grassy communities and their gradual transformations into forest communities. In the study presented by Galon (1958), one can also find a map with the distribution of dune communities in Poland, as well as research issues undertaken in Poland on dune areas until the mid-20th century. The author emphasizes that some attention should also be given to a teamwork completed on the initiative of the Scientific Society in Torun, particularly from the methodological point of view. The team consisted of a geographer, petrographer, botanist, zoologist and ecologist, and the project dealt with the Zadroże Dune to the south of Toruń.

In the initial part of the aforementioned monograph, there are two articles presented, which include maps of the studied area. One of the them, prepared by a geographer, presents the location, substratum and the relief. Another one, written by botanists, presents the variability of plant communities within the studied dune and the distribution of populations of the dominant plant species. Both articles constitute a starting point for the analysis of ecological processes taking place in populations of plants, as well as groups of animals and fungi.

The objective of this paper is to present the ensuing vegetation changes on the Zadroże Dune after 1948, as well as to describe the contemporary state of the flora and vegetation, which in the future can be a reference point for comparisons. Maps, aerial photos and interviews with local people, who live in the neighbourhood of the studied dune, constituted the source of information on its former states. The information on the current vegetation structure of the studied dune was acquired from a high-resolution satellite image and the direct exploration of the area. When comparing the past and contemporary conditions, the GIS technology and methods of satellite remote sensing were applied.

\section{The study area}

\subsection{Geographic location of the Zadroże Dune}

The Zadroże Dune is located within the commune of Wielka Nieszawka, near the south-western boundary of the city of Torun. According to physical-geographical division of Poland presented by Kondracki (1988), the area is situated within the macroregion of the Torun-Eberswalde ice-marginal Valley and the mesoregion of the Torun Valley. The studied dune is located ca. $5 \mathrm{~km}$ behind the Vistula road bridge in Torun, in the place where the road to Inowrocław and to the southern ring road of Torun branches off from the former road to Bydgoszcz (Fig. 1). The dune stretches parallel with the Bydgoszcz road. Its western part is gently 


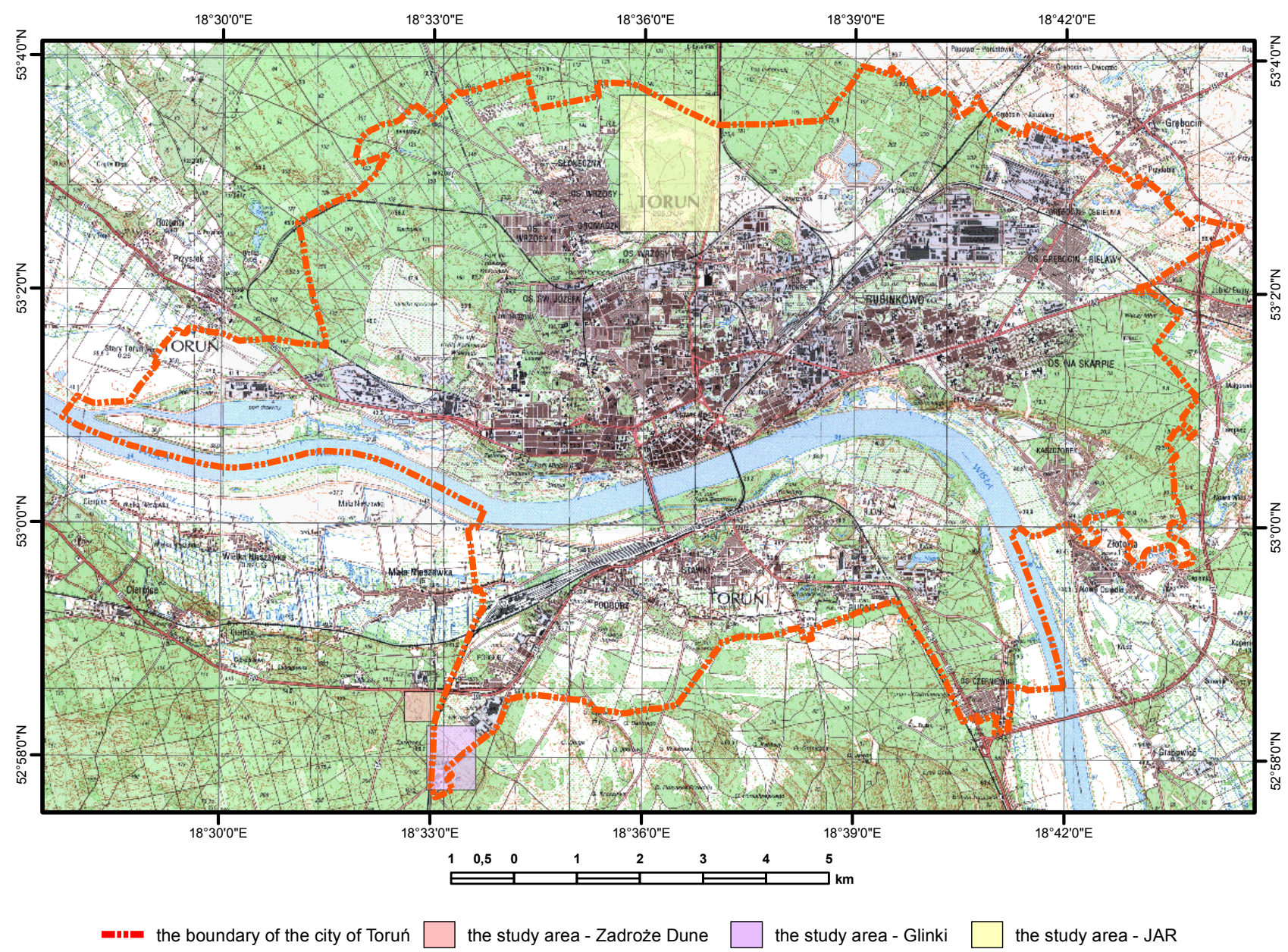

Figure 1. Location of the research heath areas - Zadroże Dune, Glinki and JAR on the topographic map of Toruń, scale 1:50,000

bent towards the south-west, where it meets with neighbouring low dune hills through a hardly visible elevation. Along the western end of the dune, a road runs towards the town of Inowrocław. Along this section, the road is adjusted to morphological conditions of the terrain - it uses a depression in the ground, west of the Zadroże Dune, running from its end through a shallow excavation towards the south-west (Okołowicz 1949).

To the south of the dune and parallel with it, there are situated rows of graves of the military graveyard with Soviet soldiers from the 2nd World War. At the fork of the roads to Bydgoszcz and Inowrocław, there is a memorial commemorating the soldiers buried here, war prisoners from the nearby Stalag XX A.

\subsection{Morphology of the dune}

According to the description provided by Okołowicz (1949), the total length of the dune embankment amounts to ca. $330 \mathrm{~m}$, whereas the maximum width in its eastern end - ca. $110 \mathrm{~m}$. The altitude of the eastern and central part of the dune is more or less at the same level - ca. $62 \mathrm{~m}$ asl (Fig. 2). The maximum altitude of the dune, which is $62.7 \mathrm{~m}$ asl is located in its central part. In its western part, the altitude of the dune gradually decreases to 59.0 and $57.0 \mathrm{~m}$, and finally it disappears when it curves towards the south. The top line in the longitudinal profile forms few small hills. Whereas the eastern part of the dune ends abruptly and unnaturally, which gives the impression that the area has just been dug up (Okołowicz 1949). In this place, before the afforestation of the dune, its surface was covered with bare quicksand, which could has covered up the possible excavation. The top surface area of the eastern part of the dune is broad, flattened and even somewhat concave. The hollow probably developed as a consequence of sand blowing off the dune, during the period when the dune was not afforested. Towards the west, the ridge of the dune becomes narrow. According to the description provided by Okołowicz in 1949, the slopes of the dune are asymmetrical; the northern slope is more steep with the 


\section{Digital Elevation Model of Zadroże Dune}

a) south-western view

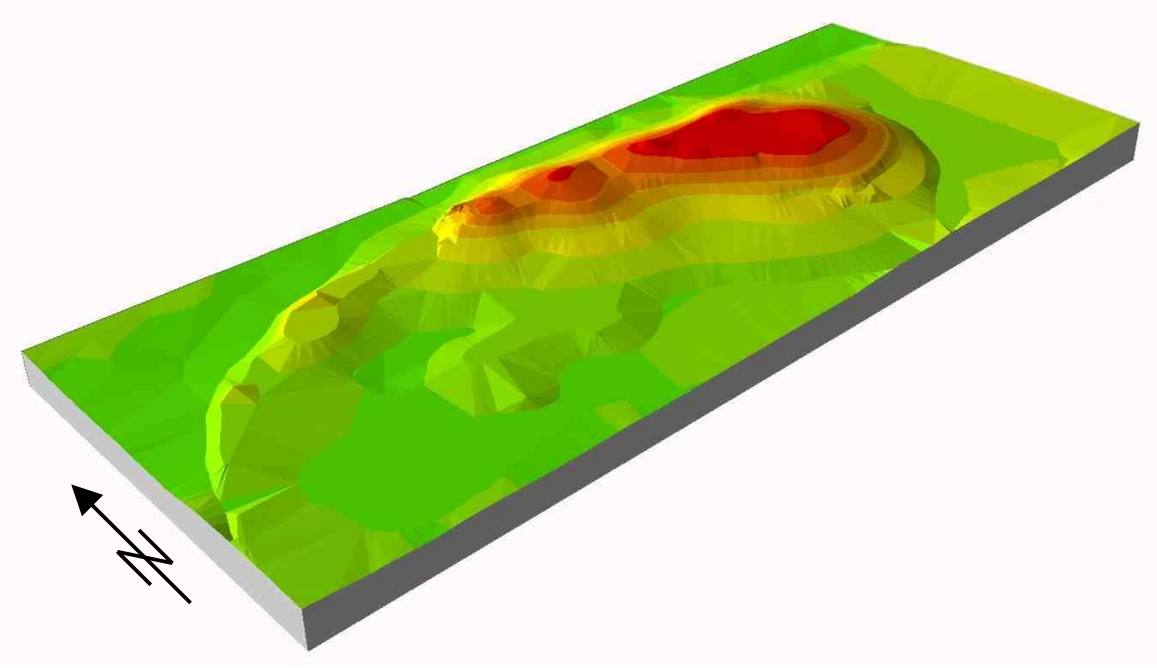

b) north-eastern view

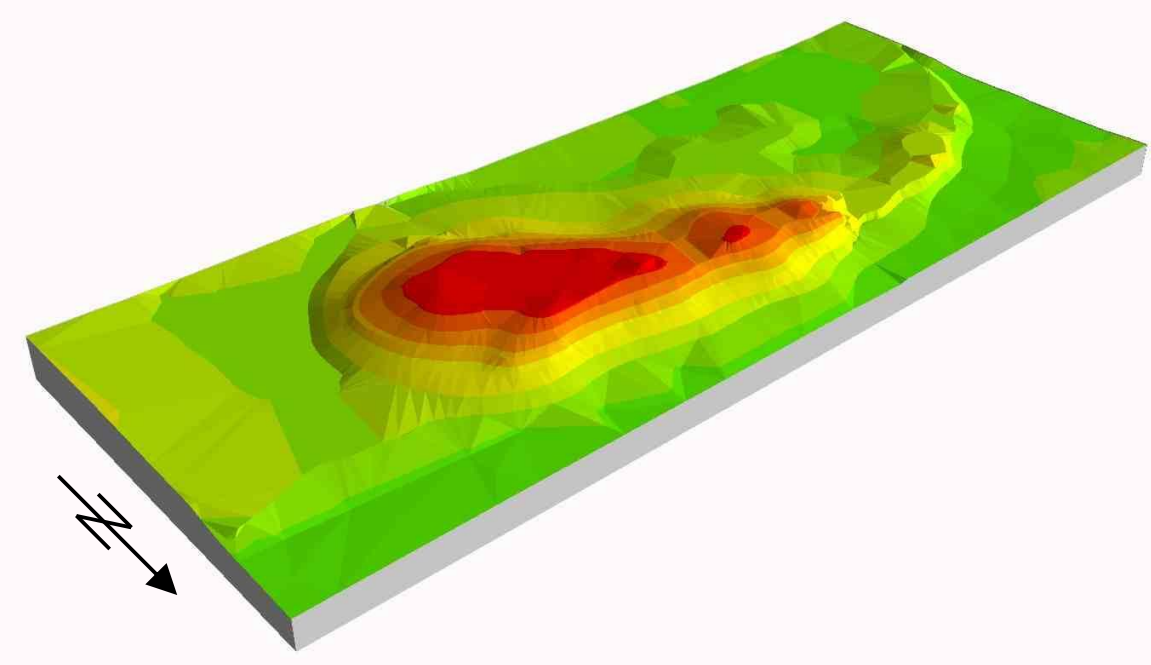

double vertical exaggeration of the model was applied in the vizualization

Figure 2. Three-dimensional visualization of the Digital Elevation Model of the research area Zadroże Dune: a) south-western view, b) north-eastern view 
inclination from $13^{\circ}$ to $15^{\circ}$ and the southern one is more gentle - ca. $7^{\circ}$. The western part of the dune is separated from its central part by an irregular ditch. The ditch is located at the exit of the road track (perpendicular to the Bydgoszcz road), which runs from the graveyard, i.e. from the south towards the dune, where it disappears. From the northern side of the dune, i.e. from the Bydgoszcz road, the ditch is considerably widened as a consequence of further sand removal.

From the analysis of contemporary cartographic materials performed with the GIS technology, it appears that the maximum relative altitude of the dune is $62.7 \mathrm{~m}$ asl, whereas the minimum altitude is $55.3 \mathrm{~m}$ asl. And thus, the absolute altitude amounts to $7.4 \mathrm{~m}$. At present, the average inclination of the terrain projected on the maps from 1949 amounts to $3.6^{\circ}$. Polygons with the inclination from 0 to $2^{\circ}$ and from 2 to $7^{\circ}$ cover the largest area on the numerical map, i.e. $47.40 \%$ and $35.17 \%$ of the total analysed area, respectively. Polygons with the inclination from 7 to $15^{\circ}$ cover $15.95 \%$, from 15 to $35^{\circ}-1.41 \%$ and above $35 \%$ only $0.07 \%$.

Areas with northern exposure, as well as flat areas dominate; they cover $19.76 \%$ and $19.36 \%$ of the total analysed area, respectively. Lands with southern exposure constitute $13.09 \%$ and lands with south-western exposure $-12.68 \%$. Areas with north-western exposure cover only $8.56 \%$ and with western exposure $-8.16 \%$. Lands with eastern and north-eastern exposure cover the smallest area: $5.73 \%$ and $5.49 \%$ respectively.

The contemporary relief of the Zadroże Dune is presented in Figure 3.

When analysing the geomorphology of the area around the dune, and particularly the influence of the anthropogenic factor, Okołowicz (1949) reached the following conclusions:

1. The surroundings of the dune underwent some artificial transformations due to exploitation of sand, as well as due to other works related to construction of roads and railway embankments.

2. Also the dune itself was subject to certain changes. Probably, it is a part of a larger dune - its northern or north-western wing.

3. Alternatively, the head of the dune, which most probably does not exist as a result of destruction, could have the north-eastern or eastern exposure. Its altitude could be similar to the altitude of the eastern part of the ,survived" dune. This kind of dune shape could be attributed to western or south-western winds. At the same time, the latter direction could explain the asymmetry of inclination of the „survived” (i.e. existing today) part of the dune.

4. The Zadroże Dune is situated in the ice-marginal valley of the Vistula River, on a terrace with the relative altitude of ca. 18-20 m, by the edge (or perhaps partly on the edge) of a higher terrace step with the relative altitude of ca. $22 \mathrm{~m} \mathrm{(56} \mathrm{m} \mathrm{asl).} \mathrm{Both} \mathrm{of} \mathrm{these} \mathrm{terraces}$ are diluvial; their surface area is built of terrace sediments - mainly of fluvioglacial origin. These terrace sediments provided the building material for the dune. Mechanical and petrographic analysis of sand from the studied dune, carried out by Gajdówna (1949), produces a result consistent with the above opinion, revealing that in a studied sample ca. $20 \%$ of sand grains is of „fluvial” origin, whereas the remaining part (ca. 80\%) is of ,fluvioglacial” origin.

\subsection{Afforestation of the dune}

In relation to the entire research carried out on the Zadroże Dune, afforestation in the past years becomes an extremely significant issue. As a proof of its past afforestation, one can mention, among others, the soil occurring either on the surface or beneath the cover of eolian sands (and thus „fossil” soil), as well as remains of tree trunks. In places where the former „forest" soil appears on the surface, it is mainly destroyed. On the vegetation map, compiled by Anikiejówna and Gorska (1949), the forest was present only on the south-western patch of the studied area. According to the map, its area amounted to 0.05 ha, what constituted only $0.9 \%$ of the total study area (5.48 ha). The remaining part of the research area - ,the Zadroże Dune” - was covered with sand (1.04 ha), non-forest plant communities (including xerophytic meadows 2.09 ha; roadside grasslands $0.98 \mathrm{ha}$; heaths $0.59 \mathrm{ha}$; the cemetery $0.28 \mathrm{ha}$ ) and technical infrastructure (roads, the monument, ruins of buildings, altogether ca. 0.45 ha).

According to Okołowicz (1949), the whole dune was afforested before 1848 and probably sometime after that, this is confirmed by a map found in the collection of ,the Town Library" in Torun. On this map, the area of the dune, adjacent in the south to the present-day Bydgoszcz road, is afforested. Unfortunately, the map does not have any information on the issue date, except for the handwritten note with the date of 1848 .

However, the local population that lived in this territory in 1948 does not remember any forest on that dune. This could prove that the forest was cut down relatively long time ago. According to assumptions by engineer $\mathrm{Mr}$ Syski, a former forester in this area (Okołowicz 1949), it happened in ca. 1870. The time when the forest was cut down coincides with the time of different land use. Years ago, the border ran through the dune (included the dune). According to the information, this change was done around 1870 , later the area with the dune was sectioned off from this district (during the interwar period). However, no attempt of the dune afforestation was made until 1948. According to Mr Syski, single trees that grew on the dune in 1949, came from „self-seeding”. 

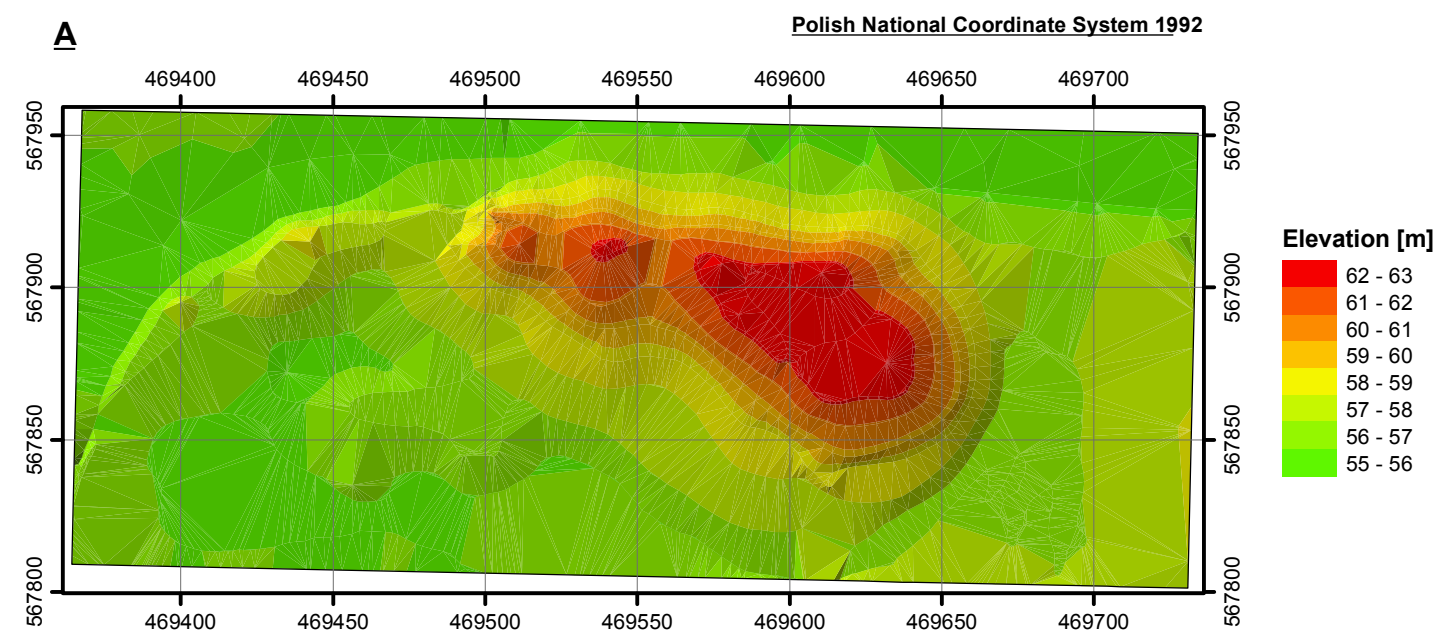

B

Polish National Coordinate System 1992
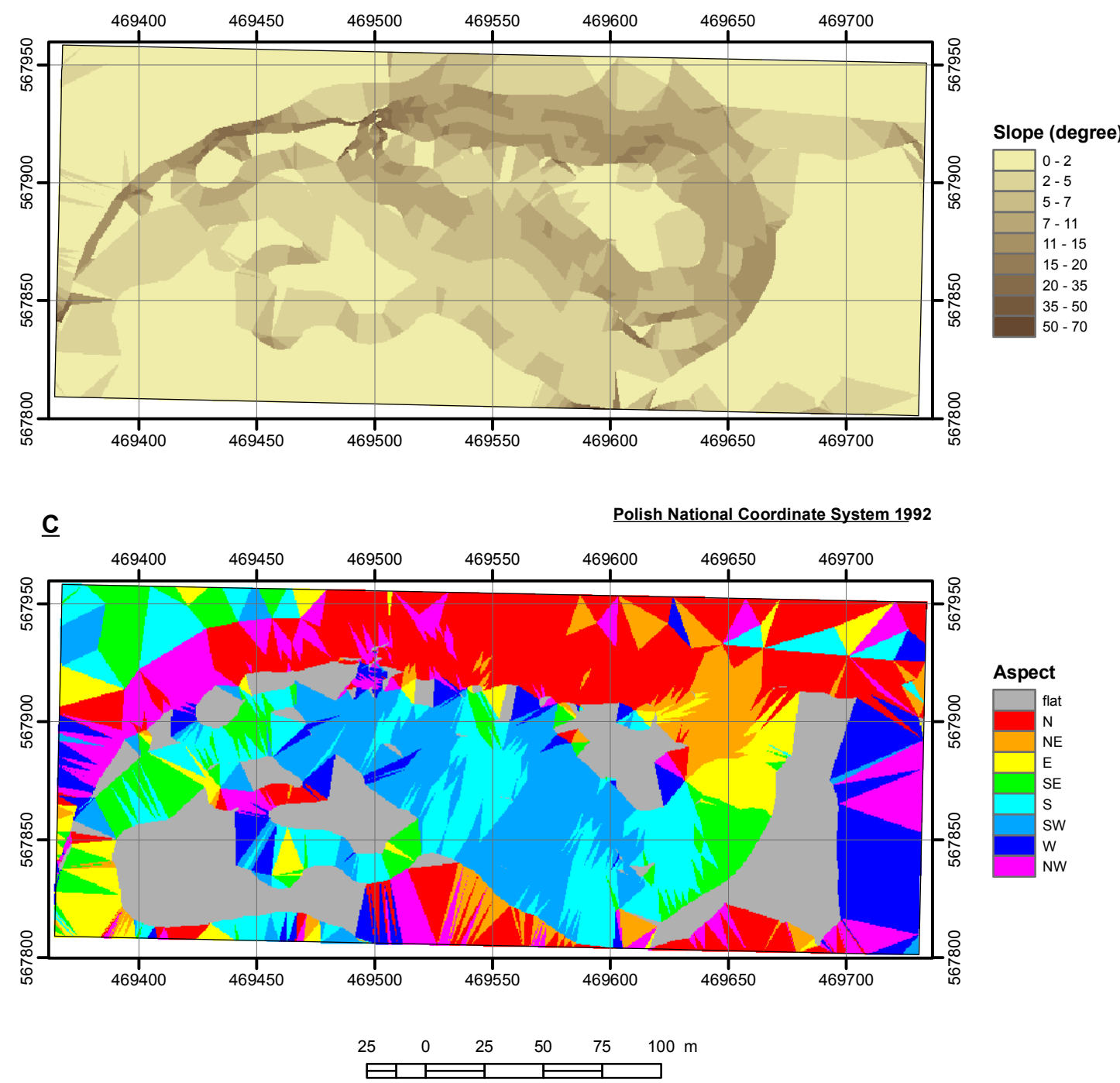

Figure 3. Selected thematic maps of the research area Zadroże Dune: a) a map of altitude, b) a map with inclination of slopes (in degrees), c) a map with exposure of slopes 


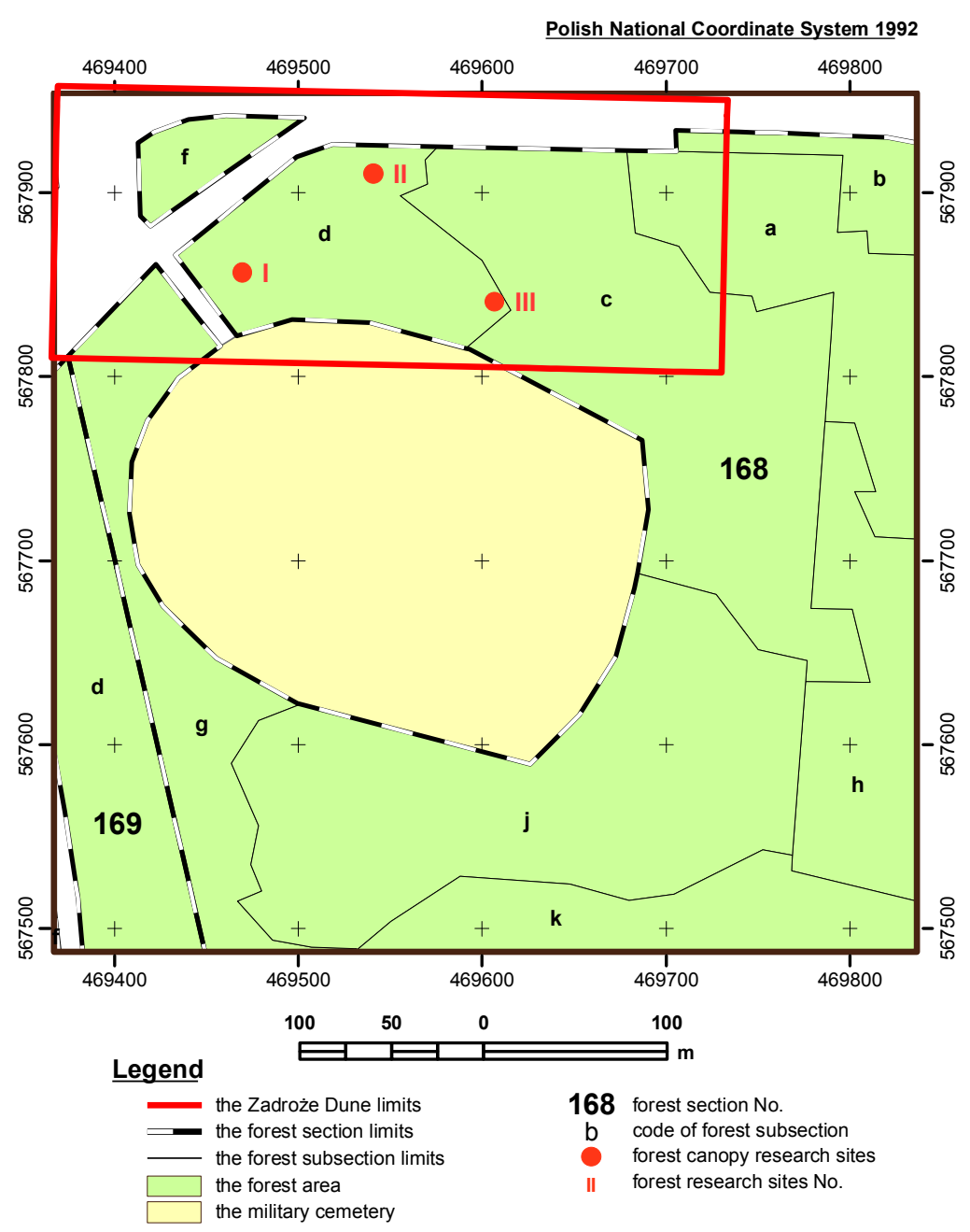

Figure 4. Spatial division of the surroundings of the Zadroże Dune into forest sections and subsections together with the location of forest-canopy measurement sites. The historical research area of the Zadroże Dune is marked with the red line

Between 1870 and 1949, self-seeding and spontaneous afforestation of the dune took place since the forest was cut down. The process of forest development proceeded, however, extremely slowly and therefore the encroachment of forest on a larger scale was impossible in the studied area. The human activity could stand in the way of this natural process. Moreover, the development of those forest areas could also be inhibited by small amount of precipitation, which are characteristic of the Kujawy region.

Today, the Zadroże Dune is covered with pine forest. It is included within the section no. 168 (subsections a, b, c, d, f, g) of the Cierpiszewo Forest Division (Fig. 4). The forest was reconstructed soon after the research was completed in 1949. The first fragment of the dune (subsection 168 d) was afforested in 1950. Further afforestations took place in 1959 (subsection 168 c), 1966 (168 a) and 1983 (168 b). Due to incomplete archival materials, it is difficult to establish what kind of farming treatments were applied in these subsections by 1992 . From 1992 till 2009, the following farming treatments were applied in individual subsections:

168 a - early clearance in 2002 ,

$168 \mathrm{~b}$ - late clearance in 1997, completion on the area of 0.05 ha in 2000 , early clearance in 2008 ,

$168 \mathrm{c}$ - late clearance in 1996, late clearance in 2009 ,

$168 \mathrm{~d}$ - late clearance in 2000 and 2009 ,

$168 \mathrm{f}$ - late clearance in 2009 ,

$168 \mathrm{~g}$ - incidental felling in 2007, late clearance in 2009.

Nowadays, the total area of the forests in the research area of Zadroże Dune comes to 3.71 ha, which makes up $67.7 \%$ of the total area. The remaining part is covered with roadside grasslands 0.81 ha, technical infrastructure (roads, the monument, ruins of buildings, altogether 0.61 ha, which means the increase by 0.16 ha as compared to 1948), the cemetery (0.29 ha), heaths (only $0.03 \mathrm{ha}$ ) and xerothermic meadows (0.03 ha). 
The course of the afforestation process on the Zadroże Dune and adjacent areas are presented by temporal series of topographic maps, as well as aerial and satellite images presented in Figures 5 and 6. German topographic maps from 1909 (Fig. 5A) and 1934 (Fig. 5B), as well as the Polish map from 1948 (Fig. 5C) confirm the information that since 1950 the dune has not been afforested. The map from 1963 (Fig. 5D) shows that during this period the dune was partly afforested. This latter state is also confirmed by the aerial photo from 1961 (Fig. 6A).

\section{Methods}

Observations of the contemporary vegetation on the Zadroże Dune was carried out during the growing season of 2009. The past states were analysed based on the map, relevés and vegetation descriptions compiled by Anikiejówna and Gorska (1949). The numerical map of the compared states was drawn up with the licensed programmes, such as desktop - ArcGIS ArvView 9.3 company ESRI. For spatial analyses, the following extensions of this software were applied: 3D Analyst, Spatial Analyst, Military Analyst and Survey Analyst. The vegetation map and the altitude plan of the dune from 1948, as well as the map of the forest canopy in the Forest Division of Cierpiszewo from 2005, were plotted on the scanned and inscribed map, in the system of coordinates from 1992, the scale $1: 10,000$. Analysis of the forest range changes in the region of the Zadroże Dune was based on all available historical cartographic materials. Also a series of aerial photos and a high-resolution satellite image IKONOS were used in the analysis of the afforestation process on the dune. A list of applied cartographic and remote-sensing materials are provided in Figures 5 and 6.

In the land cover measurements for 2009, the geodesic GPS receiver was applied - TopCon HiperPro. Field coordinates were obtained in the RTK mode (Real Time Kinematic), and corrections of coordinates - from the ASGEUPOS network.

Based on altitude measurements from 1949, the main numerical map and direct field measurements in 2009, the Digital Elevation Model (DEM) was compiled. The direct measurements were meant to increase the density of the measurement network. Based on the aforementioned data, the TIN (Triangular Irregular Network) model was created, and then a 1 metre grid. In the three-dimensional visualization, two-time vertical magnification of the model was applied. Using the DEM, the map of inclination and the map of exposure was compiled for the area.

In order to characterize the structure of the forest canopy in three pine plantations of ca. 60, 50 and 30 years old, sites of $400 \mathrm{~m}^{2}$ were delimited, within which the number of trees was determined, as well as their breast height diam- eters DBH were measured and their height. When selecting these sites, the guideline was to make sure that each of them was representative of three main age classes of the forest canopy, evident in the forest complex. The distribution of these types does not overlap with boundaries of subsections a, b, c, d within the section 168 of the Cierpiszewo Forest Division. Probably, it is a consequence of the fact that the afforestation was implemented in different years, successfulness of cultivations was not high and it was necessary to restock them during few years after the main treatment of forest reconstruction. Results from the test plots were calculated as per area covered by three age categories of the forest canopy, and then these values were added up to calculate the total biomass of the main forest canopy within the whole forest area of the Zadroże Dune.

The contemporary vegetation map of the Zadroże Dune was drawn up based on the direct field charting, carried out with the GPS receiver. Vegetation patches were distinguished according to age heterogeneity of the upper layer of the forest canopy (layer a), and according to the presence of the undergrowth, which is distinguished by species composition (layer b). Also the species and quantitative composition of the herbaceous vegetation layer (c), as well as the layer of mosses and lichens (d) were taken into consideration. Particular attention was paid to the distribution of heather patches. The number of patches created by the species Calluna vulgaris was calculated together with their area. Inclination and exposure were determined for slopes on which patches of heather occur, as well as the area of patches within particular ranges of inclination and exposure of the terrain.

During the vegetation charting, also a list of all plant species from the following taxonomic groups was compiled: lichens, bryophytes, vascular plants. Vascular plant species were divided according to families. The number of species was calculated within each family of vascular plants, as well as within lichens and bryophytes.

Lichens were identified with standard methods (e.g. Nowak \& Tobolewski 1975; Purvis et al. 1992; Wirth 1995). Specimens from the genus Cladonia, from the group chlorophaea, which were not subject to thin-layer chromatography TLC (Orange et al. 2001) were defined as Cladonia chlorophaea s.l. Herbarium materials were deposited in the Herbarium of the Institute of Ecology and Environment Protection NCU in Torun (TRN).

Floristic lists were compiled in the form of tables. Nomenclature of lichens was accepted mainly after Diederich et al. (2009) and Santesson et al. (2004). Nomenclature of bryophytes was accepted according to the list of Ochyra et al. (2003) and Szwejkowski (2006). Also keys for identification of mosses were used, compiled by Szafran (1957, 1961, 1963), Rejment-Grochowska (1971), Frahm and Frey (1992), and Damsholt (2002). In the case of vascular plants, nomenclature according to Mirek et al. (2002) was 


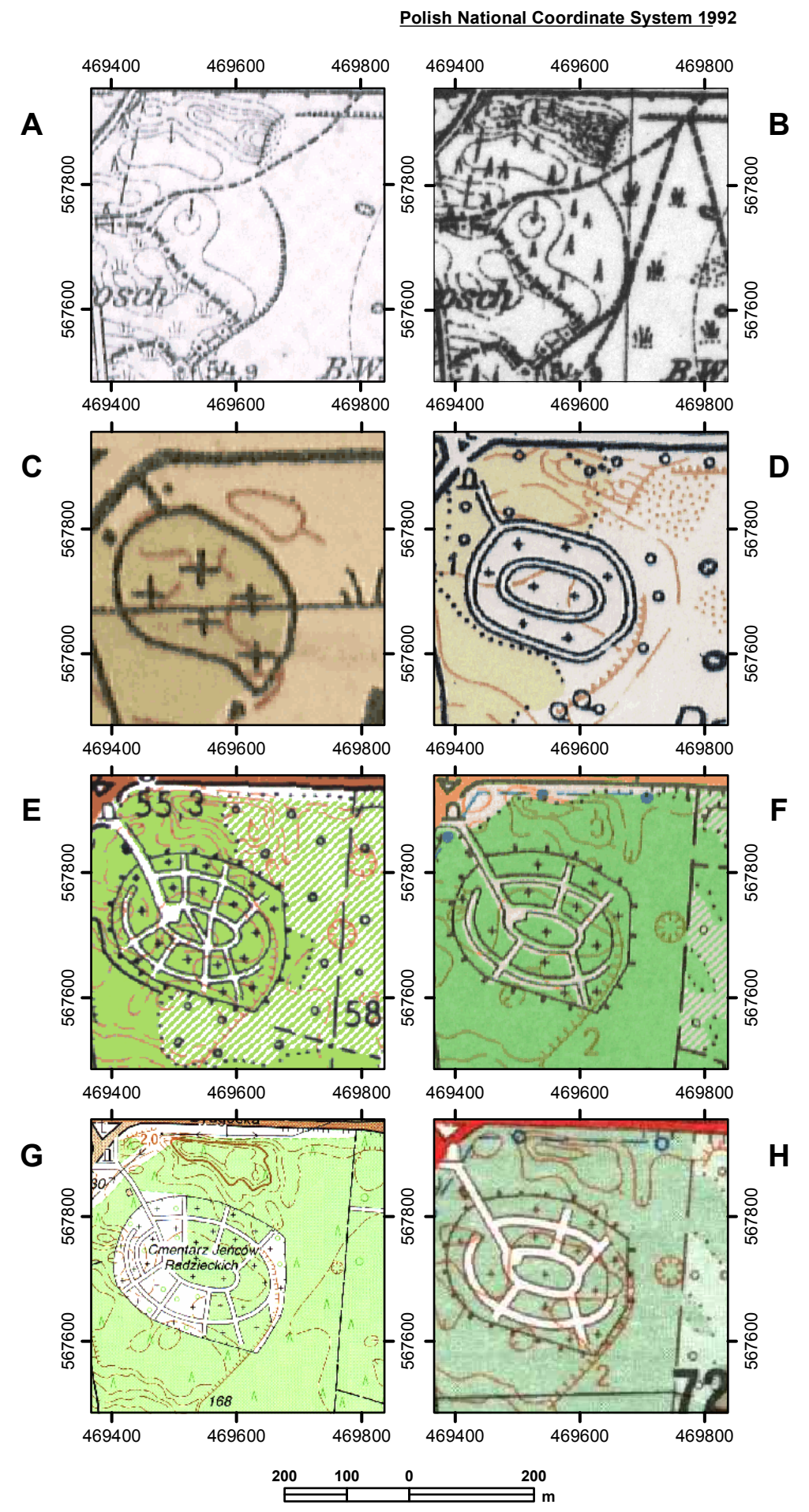

Figure 5. The surrounding area of the research area Zadroże Dune on the available cartographic materials: A - German topographic map of 1909, the scale 1:25,000 (sheet 1583 - Podgorz); B - Prussian topographic map of 1934, the scale 1:25,000 (sheet 3077 - Podgorz); C - topographic map of WIG (Military Geodetic Institute) of 1948, the scale 1:50,000 (row 37, column 27 - Ciechocinek-A); D - topographic map of 1963, the scale 1:25,000 (sheet no. 8), Polish National Coordinate System (PUWG) 1965; E - topographic map of 1971, the scale 1:25,000 (sheet 355.32 - Toruń), PUWG 1965; F - topographic map of 1987, the scale 1:25,000 (sheet N-34-110-A-a - Podgórz), PUWG 1942; G - topographic map of 2000, the scale 1:10,000 (sheet N-34-110-A-a-1 - Mała Nieszawka), PUWG 1992; H - military topographic map of 2003, the scale 1:25,000 (sheet N-34-110-A-A,B), WGS-84 
Polish National Coordinate System 1992
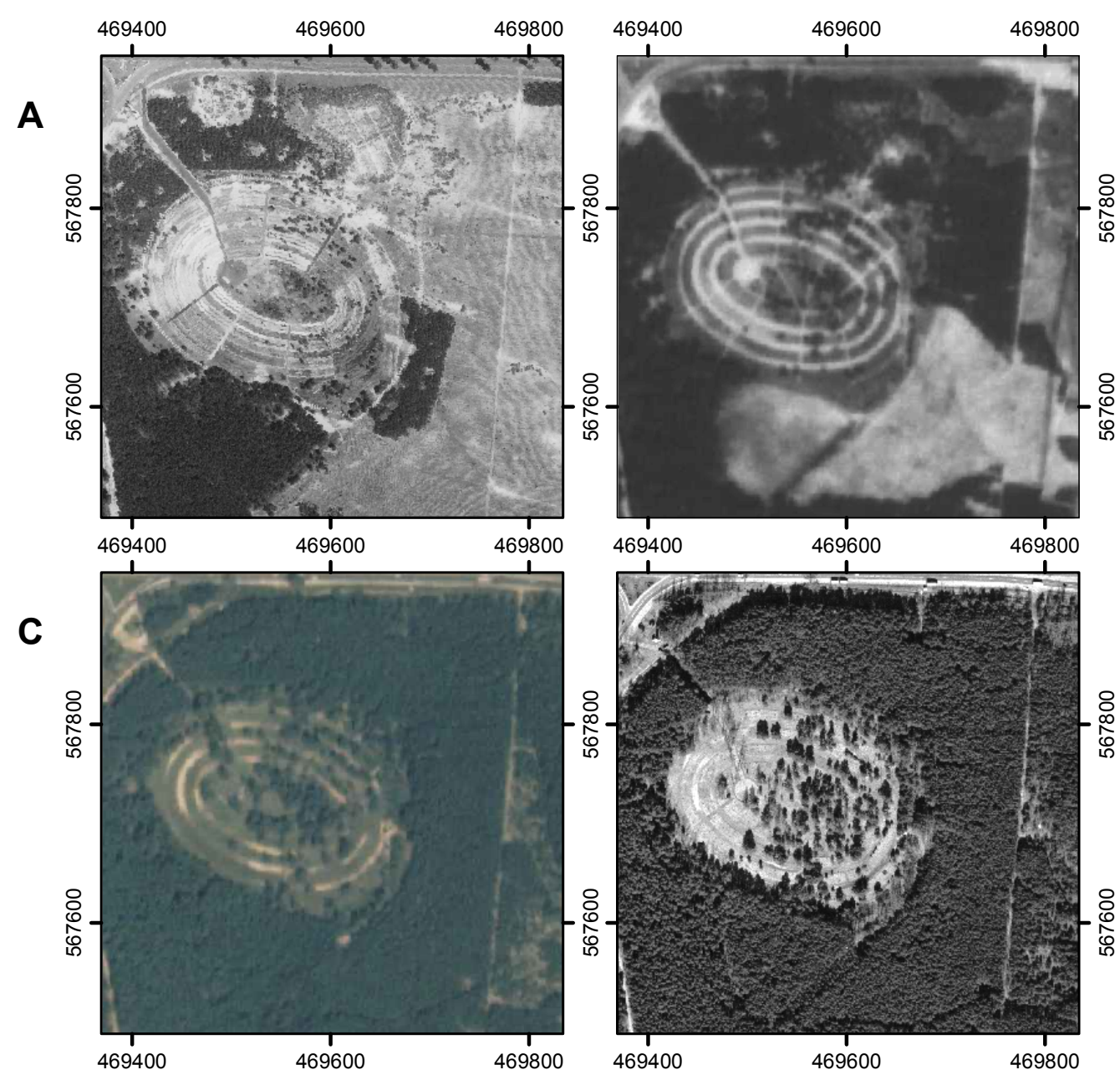

B

8

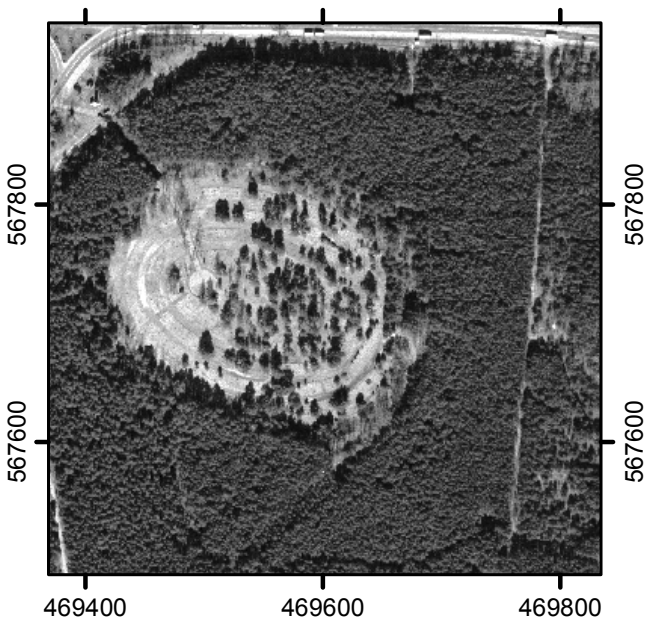

E
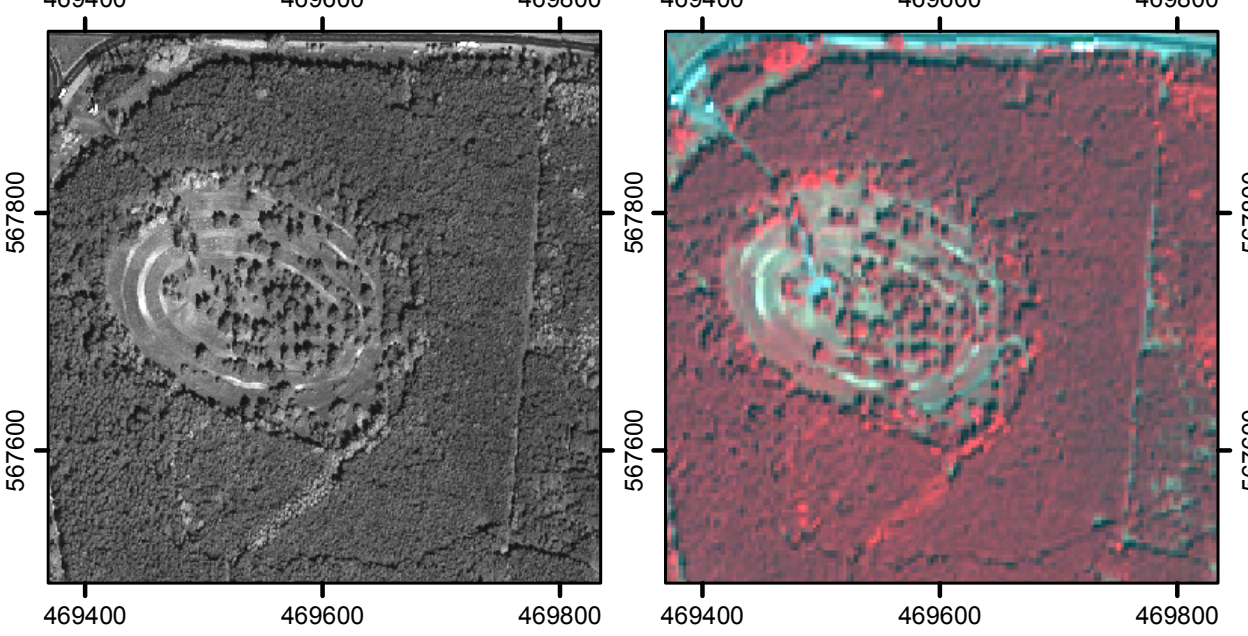

F

$\stackrel{8}{0}$

D

8
$\circ$
0

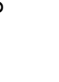


applied. In a separate overall table of vascular plants, compiled in the taxonomic system, apart from species names, also the information was provided on the affiliation of a given species with geographical-historical and syntaxonomic groups, as well as its life form.

The geographical-historical classification, based on the origin and the extent of species domestication, was performed in accordance with the proposal of Mirek (1981) and Kornaś (1968). The following geographical-historical groups were distinguished:

- non-synanthropic spontaneophytes $(\mathrm{Sn})$ - native species, occurring exclusively on natural and semi-natural habitats,

- synanthropic spontaneophytes - apophytes (Ap) - native species, domesticated on anthropogenic habitats,

- archaeophytes (Ar) - species introduced or developed by 1492 , permanently domesticated,

- kenophytes $(\mathrm{Kn})$ - species introduced or developed after 1492, permanently domesticated,

- diaphytes (Df) - not permanently domesticated species, transiently introduced and naturalized from cultivation.

Affiliation of species with geographical-historical groups, was mainly accepted after the paper by Celka (2004), and if no data were available after Chmiel (1993).

In order to evaluate the extent of synanthropization of the studied flora, coefficients defined by Jackowiak (1990) were applied. They represent the percentage contribution of specific geographical-historical groups, and are calculated with reference to the entire analysed flora.

The following indices were calculated:

the total synanthropization index

$$
W S c=\frac{A p+A}{S p+A} \times 100 \%,
$$

the total apophytism index

$$
W A p t=\frac{A p}{S p+M} \times 100 \%
$$

the apophytism index for spontaneophytes

$$
W A p=\frac{A p}{S p} \times 100 \%,
$$

the total anthropophytism index

$$
W A n c=\frac{A}{S p+A} \times 100 \%
$$

the total archaeophytism index

$$
W A r c=\frac{A r}{S p+A} \times 100 \%
$$

the total kenophytism index

$$
W K c=\frac{K n}{S p+A} \times 100 \% \quad,(6)
$$

the index of flora modernization

$$
W M=\frac{K n}{M} \times 100 \%
$$

the index of fluctuation changes

$$
W F=\frac{D f}{S p+A} \times 100 \%
$$

The symbols applied in the above formulas denote the following groups of species: $\mathrm{Sp}$ - non-synanthropic and synanthropic spontaneophytes, Ap - apophytes, Ar - archaeophytes, Kn - kenophytes, Df - diaphytes, M - metaphytes $(\mathrm{Ar}+\mathrm{Kn}), \mathrm{A}-$ anthropophytes $(\mathrm{Ar}+\mathrm{Kn}+\mathrm{Df})$.

Description of the contribution of life forms was performed according to the classification of Raunkiaer. Main units were distinguished. In Table 4 they are denoted by commonly accepted abbreviations: $\mathrm{F}$ - phanerophytes, $\mathrm{Ch}$ - chamaephytes, H - hemicryptophytes, G - geophytes, T - therophytes, Pp - semi-parasitic plants, Ep - epiphytic plants. Affiliation to specific groups of life forms was determined according to Zarzycki et al. (2002).

The sociological-ecological classification was performed in compliance with the study of Matuszkiewicz (2001), by assigning particular species to phytosociological units at the level of classes, and then by grouping the classes of plant communities into bigger units, identified on the basis of similar habitat conditions and succession relationships (Jackowiak 1990; Chmiel 1993). This way, the following 12 syntaxonomic groups were distinguished:

1. communities of waterside therophytes (Bidentetea tripartiti, Isoëto-Nanojuncetea),

2. vegetation of meadows and pastureland (Molinio-Arrhenatheretea),

3. psammophilous and xerothermic grasslands (KoelerioCorynephoretea, Festuco-Brometea),

4. thermophilous tall herb fringe and thicket communities (Trifolio-Geranietea sanguinei, Rhamno-Prunetea),

5. acidophilous heaths and clearing communities (NardoCallunetea, Epilobietea angustifolii - Epilobion angustifolii and Fragarion vescae),

6. coniferous and acidophilous deciduous forests (Vaccinio-Piceetea, Qeurco-Fagetea), 
7. riverine forests and willow thickets, tall herb fringe and thicket communities (Salicetea purpureae, Artemisietea vulgaris - Convolvuletalia sepium),

8. marshy and boggy forests, as well as alder thickets (Alnetea glutinosae, Querco-Fagetea - Alno-Ulmion),

9. thermophilous oak forests, mesophilous deciduous forests and nitrophilous thickets (Querco-Fagetea Quercion, Carpinion, Fagion, Artemisietea vulgaris - Alliarion, Epilobietea angustifolii - Sambuco-Salicion),

10. segetal communities (Chenopodietea - PolygonoChenopodietalia, Secalietea),

11. ruderal communities (Chenopodietea - Eragrostietalia, Sisymbrietalia, Artemisietea vulgaris - Onopordion, Eu-Arction, Plantaginetea majoris - Polygonion avicularis),

12. species with unidentified affiliation.

\section{Results}

\subsection{Changes in the occurrence of heaths}

In the analysis carried out with the GIS technology, it was found that there were 12 patches of Calluna vulgaris on the Zadroże Dune in 1948. Their total area amounted to 59.21 ares. There were 4 patches with the area of more than 1 are. The largest patch of heather had 34.84 ares in area, and the smallest one -0.08 ares. From the analysis of the vegetation map published by Anikiejówna and Gorska (1949), as well as from the Digital Elevation Model of 1949, it appears that patches of common heather occurred most frequently on slopes with inclination of 2 to $7^{\circ}(51.8 \%$ of the total area of heaths) and of 7 to $15^{\circ}(26.3 \%)$. From the analysis performed according to exposure of the terrain, it appears that during that period the heather grew mainly on slopes with SW exposure (31.4\% of the total heath area) and with S exposure (26.9\%).

In 2009 there were 10 patches of heather. Their total area comes to 2.96 ares. Only one of the 10 patches had the area larger than 1 are. The area of the largest patch amounted to 1.56 ares, and the smallest - to 0.01 are. Nowadays, the heather covers mainly slopes with inclination of 7 to $15^{\circ}(90.7 \%)$ and slopes with inclination of 15 to $35^{\circ}$ (9.3\%). Heaths occurred most frequently on slopes with $\mathrm{N}$ exposure (93.1\% of the area covered by Calluna vulgaris). Applying the procedure of superposition of polygons, it was calculated that the common area, i.e. the area covered by heather in 1948 and 2009 amounted to only 1.24 are.

Changes concerning the distribution of heaths on the Zadroże Dune are presented in Figures 7, 8 and 9.

\subsection{Description of the forest canopy}

Based on the exploration of the area and dendrometric measurements, it was found that the forest canopy from the Zadroże Dune is differentiated into three main categories according to age and stand quality classification. As stated in chapter 3 , the distribution of these categories does not overlap with boundaries of subsections within the section 168 of the Cierpiszewo Forest Division.

The oldest forest canopy occurs in the western part of the dune. The oldest pine specimens are ca. 59 years old. It is the most fertile habitat. Under the canopy of pine forest, there is quite abundant brushwood and undergrowth. In its species composition, there are alien species of trees and shrubs, such as Padus serotina and Cotoneaster divaricatus. In the central part, with the highest altitude, the forest canopy consists of pine trees in the same age or somewhat younger (about 51 years old), but the habitat is less fertile. The trees were classified within the stand quality classification of III,5; brushwood and undergrowth are absent here. Further to the east, the pine forest canopy becomes younger and younger. According to the survey of the Forest Division of Cierpiszewo, its habitat was also classified as III,5. In the north-western part, which is included within the subsection $168 \mathrm{~b}$, young specimens of Tilia cordata and Acer platanoides occur in the forest canopy.

In the south-western part of the forest complex, bordering on the cemetery, several dozen specimens of Scots pine occur. They come from self-seeding, which is evident from irregular, crooked shape of their trunks. Those are probably the same trees, which were described by Anikiejówna and Gorska (1949) as young pine wilding trees. In this part of the dune, also specimens of Salix acutifolia and Robinia pseudacacia occur.

Physiognomy of the forest canopy in different parts of the forest complex growing nowadays on the Zadroże Dune, is presented by photographs from Figure 10. Location of these forest fragments is presented on the orthophotomap included in the same Figure.

Based on field observations and analysis of aerial photos, it was found that the forest fragments, represented by test plots I, II and III, cover 1.29 ha, 0.39 ha and 2.03 ha, respectively. Altogether, the contemporary forests cover 3.71 ha within the area delimited for the research undertaken 60 years ago. Table 1 presents the characterization of the forest canopy in the samples analysed at three sites. The average biomass of one tree at sites I, II and III amounted to $0.27 \mathrm{~m}^{3}, 0.24 \mathrm{~m}^{3}$ and $0.18 \mathrm{~m}^{3}$, respectively. The following wood resources were recorded per one hectare of each aforementioned forest fragments: $480 \mathrm{~m}^{3}, 308 \mathrm{~m}^{3}$ and 293 $\mathrm{m}^{3}$, respectively. Whereas, over the whole area of each forest fragment, the resources were respectively $619.20 \mathrm{~m}^{3}$, $120.12 \mathrm{~m}^{3}$ and $594.79 \mathrm{~m}^{3}$. In total, the resources of pine 
Heaths on the Digital Elevation Model of the Zadroże Dune - the state in 1949

a) south-western view

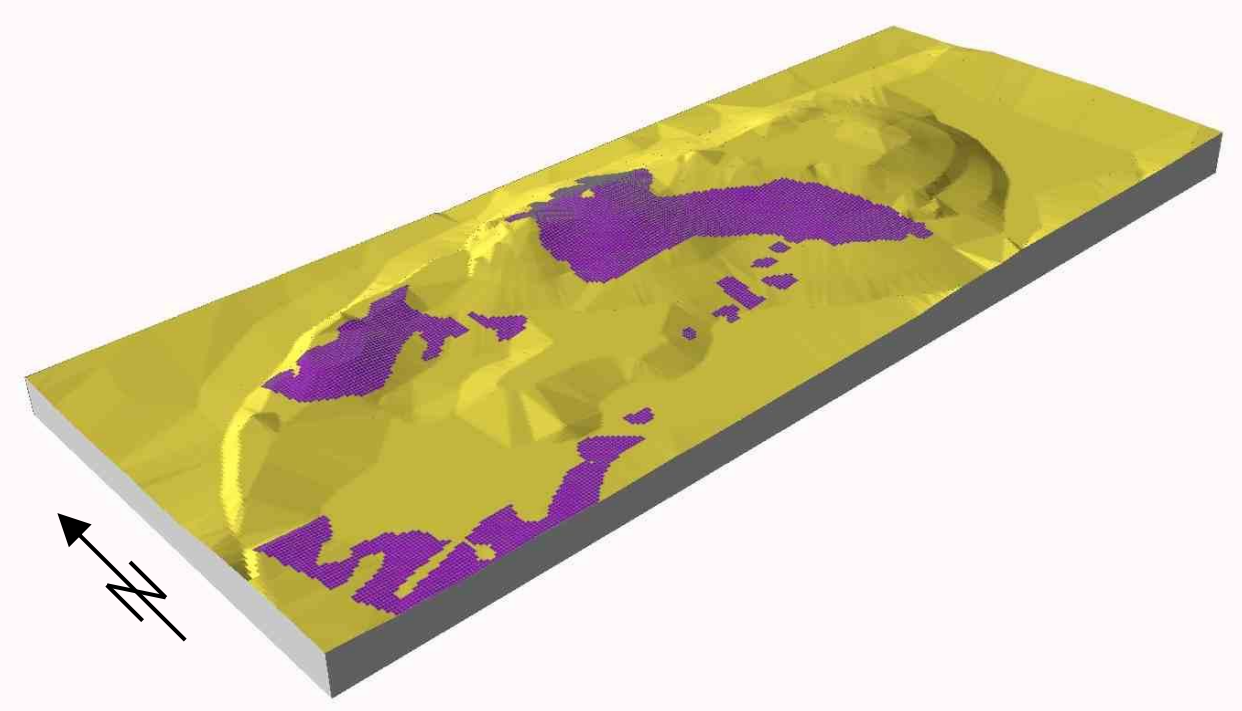

a) north-eastern view

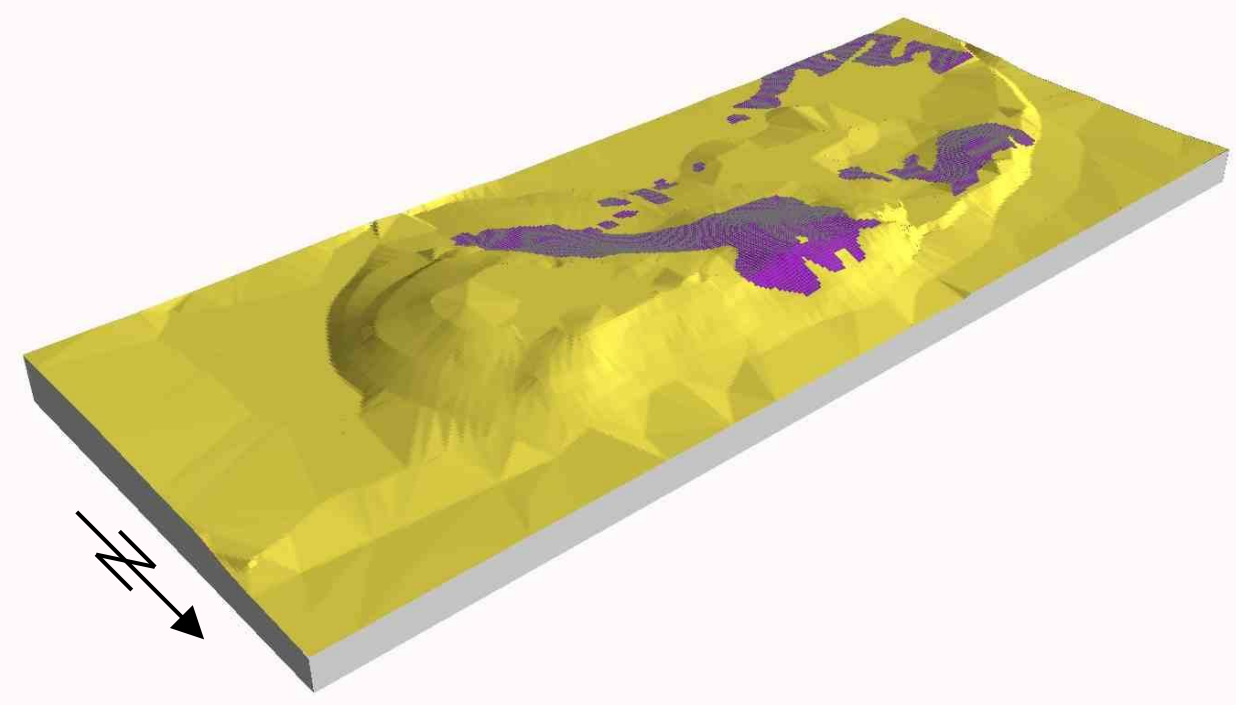

double vertical exaggeration of the model was applied in the vizualization

Figure 7. Visualization of the location of heaths on the numerical model of the area for 1948 (south-western and north-eastern views) 
Heaths on the Digital Elevation Model of the Zadroże Dune - the state in 2009

a) south-western view

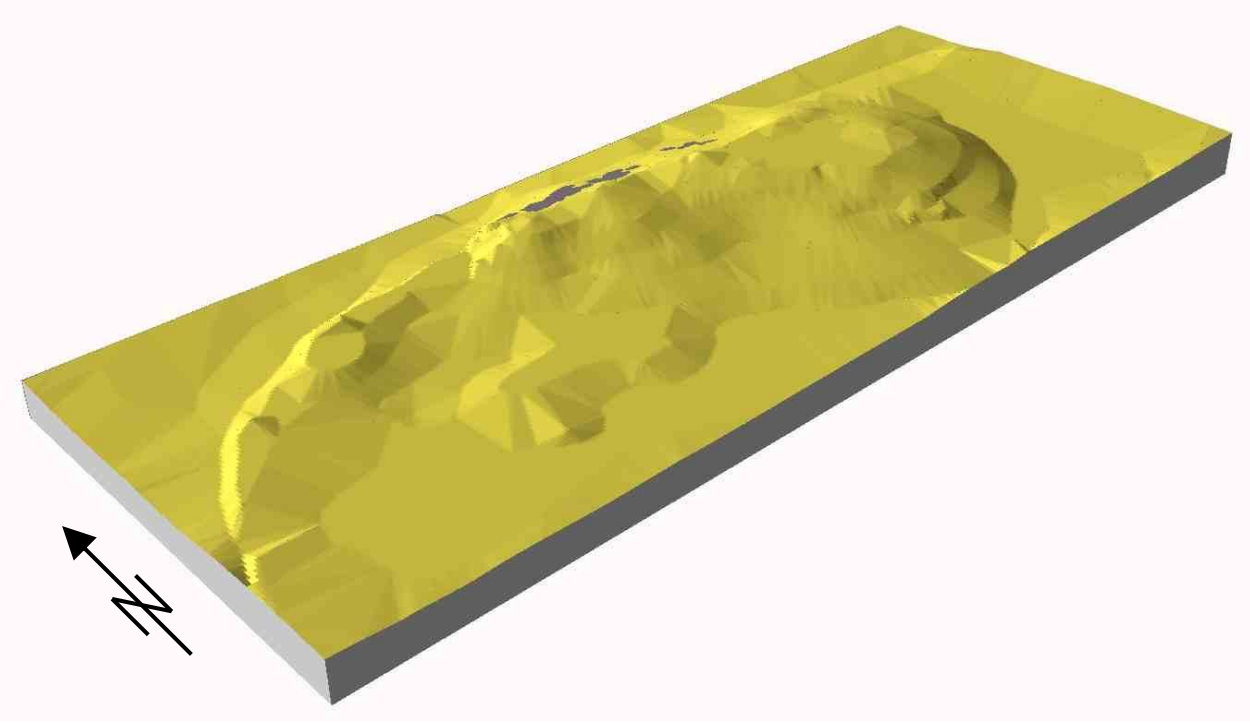

a) north-eastern view

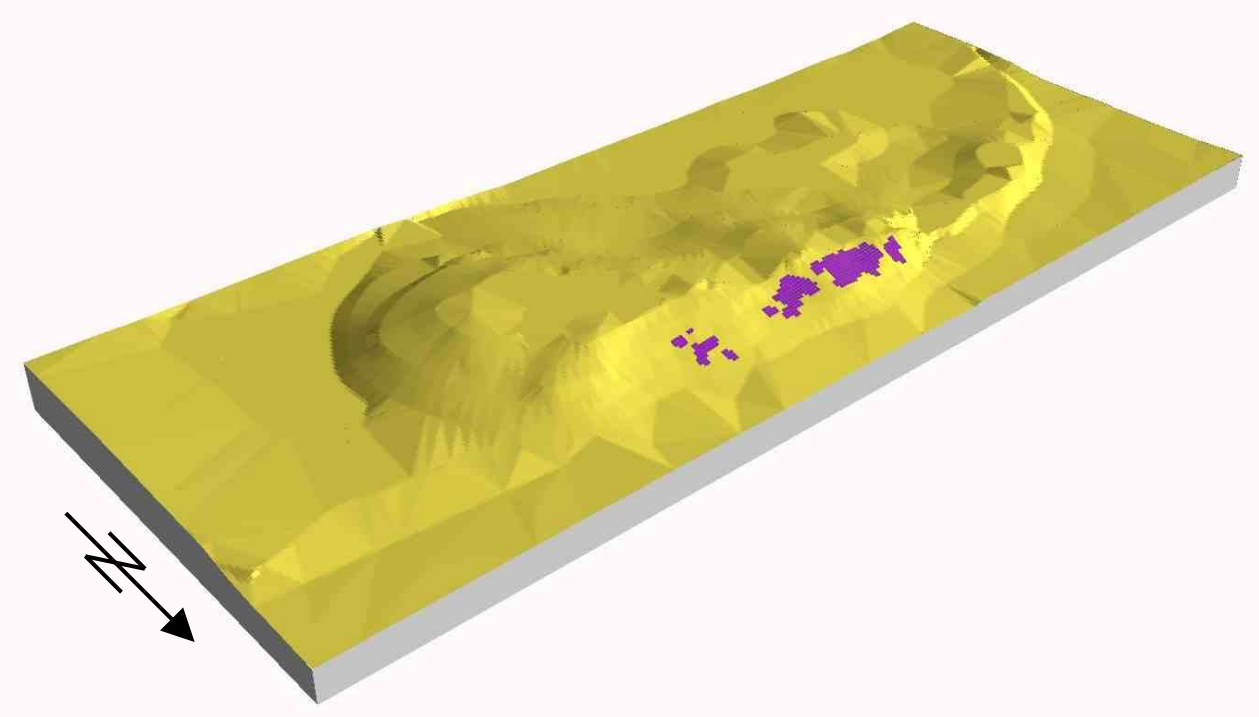

double vertical exaggeration of the model was applied in the vizualization

Figure 8. Visualization of the location of heaths on the numerical model of the area for 2009 (south-western and north-eastern views) 

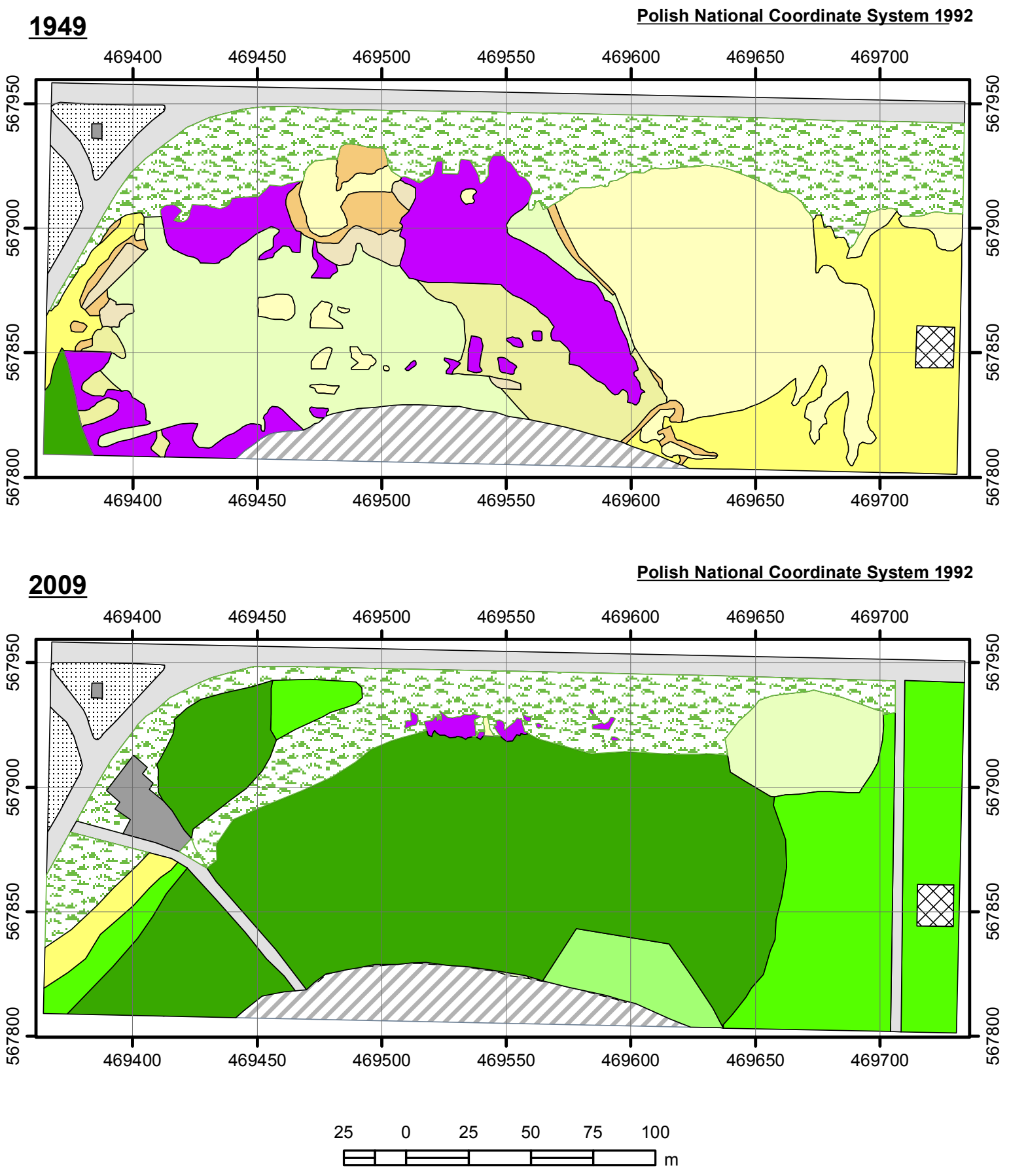

\section{Legend}

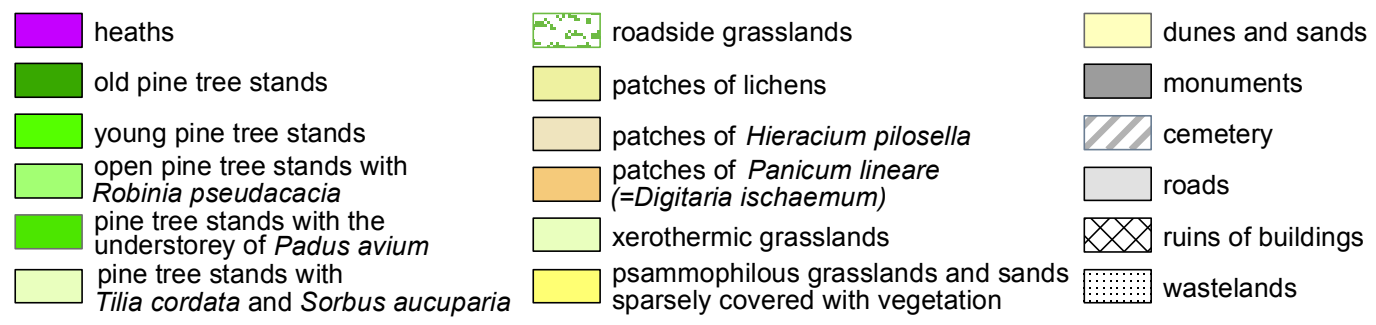

Figure 9. Land cover of the research area Zadroże Dune in 1948 and 2009 based on field charting 


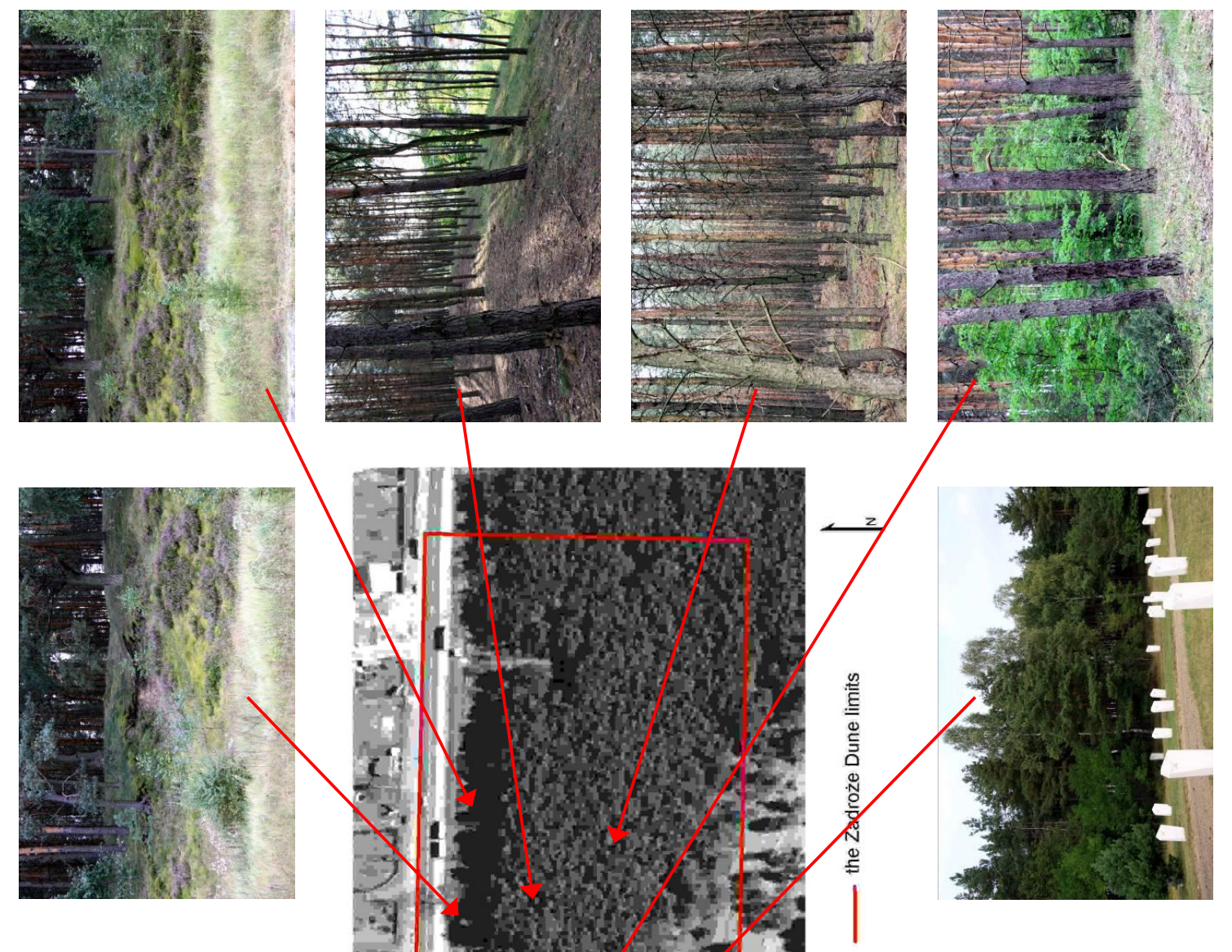

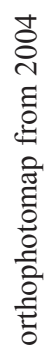

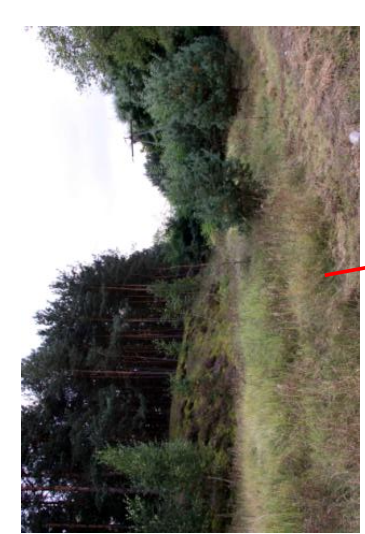

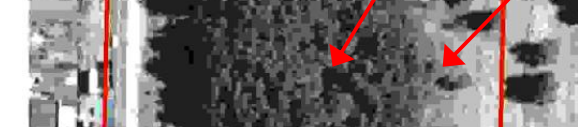

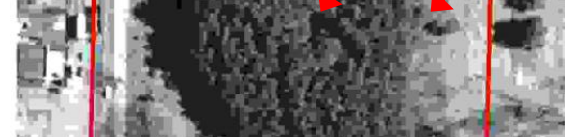

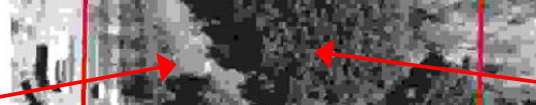
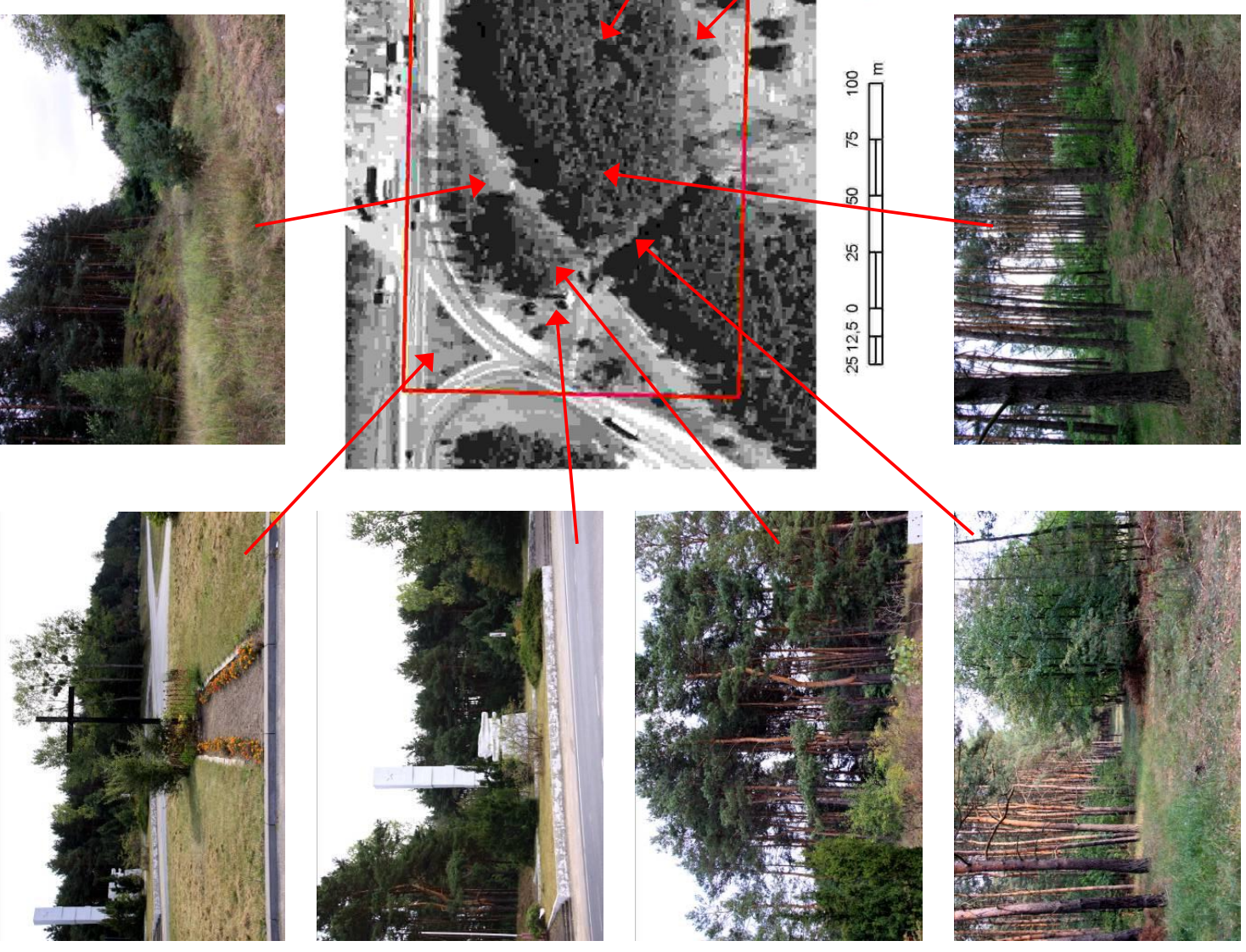

. 
Table 1. Description of the forest canopy in three fragments of the forest growing on the Zadroże Dune in 2009

\begin{tabular}{|c|c|c|c|c|c|c|c|c|c|}
\hline $\begin{array}{l}\text { Symbol } \\
\text { of forest } \\
\text { fragment }\end{array}$ & $\begin{array}{l}\text { Area } \\
\text { (ha) }\end{array}$ & $\begin{array}{c}\text { Tree } \\
\text { density } \\
\text { (ind./ha) }\end{array}$ & $\begin{array}{l}\text { Number } \\
\text { of trees in } \\
\text { area } \\
\text { (ind.) }\end{array}$ & $\begin{array}{l}\text { Wood } \\
\text { resources } \\
\text { per unit of } \\
\text { area } \\
\left(\mathrm{m}^{3} / \mathrm{ha}\right)\end{array}$ & $\begin{array}{c}\text { Wood } \\
\text { resources } \\
\text { per area } \\
\left(\mathrm{m}^{3}\right)\end{array}$ & $\begin{array}{c}\text { Average } \\
\text { breast height } \\
\text { diameter of } \\
\text { trees } \\
(\mathrm{cm})\end{array}$ & $\begin{array}{l}\text { Average } \\
\text { height of } \\
\text { trees } \\
\text { (m) }\end{array}$ & $\begin{array}{l}\text { Average } \\
\text { wood } \\
\text { resources } \\
\text { of one tree } \\
\left(\mathrm{m}^{3}\right)\end{array}$ & $\begin{array}{l}\text { Stand quality } \\
\text { classification }\end{array}$ \\
\hline I & 1.29 & 1,800 & 2,322 & 480 & 619.20 & 20.0 & 14.66 & 0.27 & III \\
\hline II & 0.39 & 1,300 & 507 & 308 & 120.12 & 18.9 & 13.61 & 0.24 & III,5 \\
\hline III & 2.03 & 1,600 & 3,248 & 293 & 594.79 & 16.6 & 12.81 & 0.18 & III,5 \\
\hline Total & & & 6,077 & & $1,334.11$ & & & & \\
\hline
\end{tabular}

Table 2. Structure of the forest canopy according to breast height diameter classes in three forest fragments covering the Zadroże Dune in 2009

\begin{tabular}{|c|c|c|c|c|c|c|c|c|c|c|c|}
\hline $\begin{array}{c}\text { Symbol of } \\
\text { forest fragment }\end{array}$ & \multicolumn{9}{|c|}{$\begin{array}{c}\text { Breast height diameter classes } \\
(\mathrm{cm})\end{array}$} & \multicolumn{1}{|c|}{} \\
\hline & $11-12$ & $13-14$ & $15-16$ & $17-18$ & $19-20$ & $21-22$ & $23-24$ & $25-26$ & $27-28$ & $29-30$ & together \\
\hline I & 0 & 258 & 129 & 903 & 129 & 258 & 258 & 129 & 258 & 0 & 2,322 \\
\hline II & 0 & 0 & 117 & 195 & 39 & 78 & 39 & 0 & 0 & 39 & 507 \\
\hline III & 406 & 812 & 203 & 812 & 609 & 203 & 0 & 0 & 203 & 0 & 3,248 \\
\hline Total & 406 & 1,070 & 449 & 1,910 & 777 & 539 & 297 & 129 & 461 & 39 & 6,077 \\
\hline
\end{tabular}

within the whole forest area of the Zadroże Dune amounted to $1334.11 \mathrm{~m}^{3}$.

Table 2 presents the structure of trees in the classes of breast height diameters. Most of the trees $31.43 \%$ occurred in the breast height diameter class of $17-18 \mathrm{~cm} \mathrm{dbh}$. About 2 and 2.5 times less trees occurred in the classes of 13-14 $\mathrm{cm}$ and $19-20 \mathrm{~cm}$, that is $17.61 \%$ and $12.79 \%$ respectively. The fewest number of trees was recorded in the highest class of $29-30 \mathrm{~cm}$, i.e. only $0.64 \%$.

\subsection{Comparison of the flora in 1948 and 2009}

\subsubsection{Comparison at the level of taxonomic units}

Based on the data published by Anikiejówna and Gorska (1949), 7 species of lichens, 5 species of mosses and 102 vascular species occurred within the Zadroże Dune in 1948 (Tables 3 and 4). In the group of lichens, epigeic species were recorded, most typical of heaths and dry pine forests. The following species were recorded in the group of mosses: Abietinella hystricosa, Hylocomium splendens, Niphotrichum canescens, Plagiomnium cuspidatum and Polytrichum piliferum, and thus also species occurring on heaths and in pine forests.
Among vascular plants, the following families are represented by the largest numbers of species: Asteraceae - 16 species, Poaceae - 14 species, Fabaceae - 11 species and Caryophyllaceae -7 species. It appears from the vegetation map presented in this paper that, at that time, the dominant species were as follows: Corynephorus canescens, Koeleria glauca, Thymus serpyllum, Helichrysum arenarium, Scleranthus annuus, Calluna vulgaris, as well as species from the genus Carex. Vegetation characteristic of the dune, occurred on quick sand, whereas rare specimens of species included on the list, were found along the periphery of this area. Plants, which reproduce vegetatively and are equipped with stolons, such as: Calamagrostis epigejos and Carex praecox, survive most easily on areas deficient in water and nutritional resources. These species are also an important factor that stabilize quick sand. Within this group of species, probably also Corynephorus canescens belongs, although this taxon prefers more stabilized sand. At the front of the dune, one could observe plants that were covered by quick sand, but some species, such as: Achillea millefolium and Agrostis canina adapted to these conditions and were developing well. Annual plants formed large patches at the edges of the dune e.g. Panicum lineare (=Digitaria ischaemum), Plantago ramosa. 
Table 3. Comparison of biota of lichens, as well as the flora of mosses and liverworts occurring on the Zadroże Dune in 1948 and 2009

\begin{tabular}{|c|c|c|}
\hline Family or species names Year and data source & $\begin{array}{l}1948 \\
\text { (Anikiejówna\&Gorska } \\
1948)\end{array}$ & $\begin{array}{l}2009 \\
\text { (Adamska, Gugnacka-Fiedor } \\
\text { \& Boinska, this study) }\end{array}$ \\
\hline Lichens & 7 & 27 \\
\hline Baeomyces rufus (Huds.) Rebent & & + \\
\hline Cetraria islandica (L.) Ach. & + & + \\
\hline Cladonia fimbriata (L.) Fr. & + & + \\
\hline Cladonia gracilis (L.) Willd. & + & + \\
\hline Cladonia pyxidata (L.) Hoffm. & + & + \\
\hline$($ Cladonia rangiferina $)=$ C. rangiformis Hoffm. & + & + \\
\hline$($ Cladonia sylvatica $)=$ Cladonia arbuscula (Wallr.) Flotow & + & + \\
\hline Cornicularia aculeata $=$ Coelocaulon aculeatum (Schr.) & + & + \\
\hline Cladonia phyllophora Hoffm. & & + \\
\hline Cladonia furcata (Huds.) Schrader & & + \\
\hline Cladonia cornuta (L.) Hoffm. & & + \\
\hline Cladonia chlorophaea (Flk. ex Sommerf.) Sprengel & & + \\
\hline Cladonia macilenta Hoffm. & & + \\
\hline Cladonia foliacea (Huds.) Willd. & & + \\
\hline Cladonia ciliata (Stirton) Trass & & + \\
\hline Cladonia uncialis (L.) Wigg. & & + \\
\hline Cladonia arbuscula subsp. mitis (Wallr.) Flotow & & + \\
\hline Cladonia coniocraea (Flk.) Vainio & & + \\
\hline Cladonia glauca Flk. & & + \\
\hline Cladonia crispata (Ach.) Flotow & & + \\
\hline Hypogymnia physodes (L.) Nyl. & & + \\
\hline Hypocenomyce scalaris (Ach.) Choisy & & + \\
\hline Lecanora conizaeoides Nyl. in Crombie & & + \\
\hline Lichenoconium lecanorae (Jaap) Hawksw. & & + \\
\hline Placynthiella icmalea (Ach.) Copp. \& P.James & & + \\
\hline Placynthiella oligotropha (Vainio) Coppins \& P. James & & + \\
\hline Trapeliopsis granulosa (Hoffm.) Lumbsch & & + \\
\hline Mosses & 5 & 42 \\
\hline Abietinella hystricosa (Mitt.) Broth. & + & + \\
\hline Aloina rigida (Hedw.) Limpr. & . & + \\
\hline Amblystegium serpens (Hedw.) Schimp. & . & + \\
\hline Brachythecium albicans (Hedw.) Schimp. & . & + \\
\hline Brachythecium campestre (Müll. Hal.) Schimp.) & . & + \\
\hline Brachythecium glareosum (Bruch ex Spruce) Schimp. & . & + \\
\hline Brachythecium rutabulum (Hedw.) Schimp. & . & + \\
\hline Brachythecium salebrosum (Hoffm. ex F.Weber \& D. Mohr) Schimp. & . & + \\
\hline Brachytheciastrum velutinum (Hedw.) Ign. \& Huttunen & . & + \\
\hline
\end{tabular}




\begin{tabular}{|c|c|c|}
\hline Ceratodon purpureus (Hedw.) Brid. & . & + \\
\hline Dicranum scoparium Hedw. & . & + \\
\hline Dicranum undulatum Schrad. ex Brid. & . & + \\
\hline Eurhynchium angustirete (Broth.) T. J. Kop. & . & + \\
\hline Hylocomium splendens (Hedw.) Schimp. & + & + \\
\hline Hypnum bambergeri Schimp. & . & + \\
\hline Hypnum cupressiforme Hedw. & . & + \\
\hline Hypnum pallescens (Hedw.) P. Beauv. & . & + \\
\hline $\begin{array}{l}\text { Niphotrichum (=Rhacomitrium) canescens (Hedw.) Bednarek-Ochyra \& } \\
\text { Ochyra }\end{array}$ & + & + \\
\hline Oxyrhynchium hians (Hedw.) Loeske & . & + \\
\hline Plagiomnium cuspidatum (Hedw.) T. J. Kop & + & + \\
\hline Plagiomnium ellipticum (Brid.) T. J. Kop. & . & + \\
\hline Plagiomnium rostratum (Schrad.) T. J. Kop. & . & + \\
\hline Plagiothecium laetum Schimp. \& Gümbel & . & + \\
\hline Platygyrium repens (Brid.) Schimp. in Bruch & . & + \\
\hline Pleurozium schreberi (Willd.) ex Brid.) Mitt. & . & + \\
\hline Pohlia elongata Hedw. & . & + \\
\hline Pohlia melanodon (Brid.) A. J. Shaw & . & + \\
\hline Pohlia nutans (Hedw.) Lindb. & . & + \\
\hline Polytrichum juniperinum Hedw. & . & + \\
\hline Polytrichum piliferum Hedw. & + & + \\
\hline Pseudocalliergon turgescens (T. Jensen) Loeske & . & + \\
\hline Pseudoscleropodium purum (Hedw.) M. Fleisch. ex Broth. & . & + \\
\hline Pylaisia polyantha (Hedw.) Schimp. & . & + \\
\hline Rhizomnium pseudopunctatum (Bruch \& Schimp.) T. J. Kop. & . & + \\
\hline Rhizomnium punctatum (Hedw.) T. J. Kop. & . & + \\
\hline Rhynchostegium megapolitanum (Blandow) Schimp. & . & + \\
\hline Schistidium (=Grimmia) apocarpum (Hedw.) Bruch \& Schimp. & . & + \\
\hline Sciuro-hypnum oedipodium Ignatov \& Huttunen & . & + \\
\hline Sciuro-hypnum reflexum (Starke) Ignatov \& Huttunen & . & + \\
\hline Sciuro-hypnum starkei (Brid.) Ignatov \& Huttunen & . & + \\
\hline Scorpidium scorpioides (Hedw.) Limpr. & . & + \\
\hline Syntrichia ruralis (Hedw.) F. Weber \& D. Mohr (=Tortula ruralis) & . & + \\
\hline Liverworts & 0 & 7 \\
\hline Cephalozia pleniceps (Austin) Lindb. & . & + \\
\hline Cephaloziella divaricata $(\mathrm{Sm})$ Schiffn. & . & + \\
\hline Cephaloziella hampeana (Nees) Schiffn. & . & + \\
\hline Chiloscyphus polyanthos (L.) Corda & . & + \\
\hline Lophocolea bidentata (L.) Dumort. & . & + \\
\hline Lophozia ventricosa (Dicks.) Dumort. & . & + \\
\hline Ptilidium ciliare (L.) Hampe & . & + \\
\hline
\end{tabular}


Table 4.Comparison of the vascular flora from the Zadroże Dune in 1948 and 2009

\begin{tabular}{|c|c|c|c|c|c|}
\hline Family or species name & $\begin{array}{l}1948 \\
\text { (Anikiejówna } \\
\text { \& Gorska } \\
\text { 1949) }\end{array}$ & $\begin{array}{l}2009 \\
\text { (Rutkowski \& } \\
\text { Kamiński, this } \\
\text { study) }\end{array}$ & $\begin{array}{l}\text { Geographical- } \\
\text { historical } \\
\text { group }^{1)}\end{array}$ & $\begin{array}{c}\text { Syntaxonomical } \\
\text { group }^{2)}\end{array}$ & $\begin{array}{l}\text { Raunkiaer's } \\
\text { life form of } \\
\text { plant species }{ }^{3)}\end{array}$ \\
\hline Number of families / Number of species & $31 / 102$ & $52 / 204$ & & & \\
\hline Family: Dryopteridiaceae & 0 & 2 & & & \\
\hline Dryopteris carthusiana (Vill.) H.P. Fuchs & & + & $\mathrm{Sp}$ & 9 & $\mathrm{H}$ \\
\hline Dryopteris filix-mas (L.) Schott & & + & $\mathrm{Sp}$ & 9 & $\mathrm{H}$ \\
\hline Family: Polypodiaceae & 0 & 1 & & & \\
\hline Polypodium vulgare L. & & + & $\mathrm{Sp}$ & 6 & $\mathrm{H}$ \\
\hline Family: Pinaceae & 1 & 2 & & & \\
\hline Pinus sylvestris L. & $+(a, b, c)^{4)}$ & $+(a, b)$ & Ap & 6 & $\mathrm{~F}$ \\
\hline Pinus nigra J.F. Arnold & & $+(a)$ & Ef & 6 & $\mathrm{~F}$ \\
\hline Family: Cupressaceae & 1 & 1 & & & \\
\hline Juniperus communis L. & $+(\mathrm{c})$ & $+(\mathrm{c})$ & $\mathrm{Sp}$ & 6 & $\mathrm{~F}$ \\
\hline Family: Ranunculaceae & 2 & 1 & & & \\
\hline Pulsatilla pratensis (L.) Mill. & + & . & $\mathrm{Sp}$ & 6 & $\mathrm{H}$ \\
\hline Ranunculus bulbosus L. & + & + & Ap & 3 & $\mathrm{H}$ \\
\hline Family: Berberidaceae & 0 & 2 & & & \\
\hline Berberis vulgaris L. & & $+(\mathrm{b})$ & Ap & 4 & $\mathrm{~F}$ \\
\hline Mahonia aquifolium (Pursh) Nutt. & & + & Ef & 12 & $\mathrm{~F}$ \\
\hline Family: Papaveraceae & 0 & 1 & & & \\
\hline Chelidonium majus L. & & + & Ap & 9 & $\mathrm{H}$ \\
\hline Family: Fagaceae & 0 & 1 & & & \\
\hline Quercus robur $\mathrm{L}$. & & $+(\mathrm{c})$ & $\mathrm{Sp}$ & 9 & $\mathrm{~F}$ \\
\hline Family: Betulaceae & 1 & 3 & & & \\
\hline Alnus glutinosa (L.) Gaertn. & & $+(\mathrm{b})$ & $\mathrm{Sp}$ & 8 & $\mathrm{~F}$ \\
\hline Alnus incana (L.) Moench & & $+(a)$ & $\mathrm{Kn}$ & 8 & $\mathrm{~F}$ \\
\hline Betula pendula Roth & $+(\mathrm{c})$ & $+(a, b)$ & Ap & 6 & $\mathrm{~F}$ \\
\hline Family: Corylaceae & 0 & 1 & & & \\
\hline Corylus avellana $\mathrm{L}$. & & + & $\mathrm{Sp}$ & 9 & $\mathrm{~F}$ \\
\hline Family: Urticaceae & 0 & 1 & & & \\
\hline Urtica dioica $\mathrm{L}$. & & + & Ap & 9 & $\mathrm{H}$ \\
\hline Family: Loranthaceae & 0 & 1 & & & \\
\hline Viscum album L. ssp. album & & + & Ap & 9 & Pp, Ep \\
\hline Family: Caryophyllaceae & 7 & 11 & & & \\
\hline Arenaria serpyllifolia $\mathrm{L}$. & + & + & Ap & 3 & $\mathrm{~T}$ \\
\hline Cerastium arvense $\mathrm{L}$. & & + & Ap & 3 & $\mathrm{H}$ \\
\hline Cerastium holosteoides Fr. emend. Hyl. & & + & Ap & 2 & $\mathrm{H}$ \\
\hline Dianthus arenarius L. & + & & $\mathrm{Sp}$ & 3 & $\mathrm{H}$ \\
\hline Dianthus carthusianorum L. & + & + & $\mathrm{Sp}$ & 3 & $\mathrm{H}$ \\
\hline
\end{tabular}




\begin{tabular}{|c|c|c|c|c|c|}
\hline Gypsophila fastigiata $\mathrm{L}$. & + & + & $\mathrm{Sp}$ & 3 & $\mathrm{H}$ \\
\hline Herniaria glabra $\mathrm{L}$. & + & + & Ap & 3 & $\mathrm{H}$ \\
\hline Melandrium album (Mill.) Garcke & & + & Ap & 11 & $\mathrm{H}$ \\
\hline Moehringia trinervia (L.) Clairv. & & + & $\mathrm{Sp}$ & 9 & $\mathrm{H}$ \\
\hline Scleranthus annuus L. & + & & Arch & 10 & $\mathrm{~T}$ \\
\hline Silene nutans $\mathrm{L}$. & & + & $\mathrm{Sp}$ & 3 & $\mathrm{H}$ \\
\hline Silene otites (L.) Wibel & + & & $\mathrm{Sp}$ & 3 & $\mathrm{H}$ \\
\hline $\begin{array}{l}\text { Spergularia rubra (L.) J. Presl \& } \\
\text { C. Presl }\end{array}$ & & + & Ap & 10 & $\mathrm{~T}$ \\
\hline Stellaria media (L.) Vill. & & + & Ap & 10 & $\mathrm{~T}$ \\
\hline Family: Chenopodiaceae & 2 & 3 & & & \\
\hline Chenopodium album $\mathrm{L}$. & & + & Ap & 11 & $\mathrm{~T}$ \\
\hline Chenopodium strictum Roth & & + & $\mathrm{Kn}$ & 11 & $\mathrm{~T}$ \\
\hline Corispermum intermedium Schweigg. & + & & Ap & 1 & $\mathrm{~T}$ \\
\hline $\begin{array}{l}\text { Salsola kali L. subsp. ruthenica (Iljin) } \\
\text { Soó }\end{array}$ & + & + & $\mathrm{Kn}$ & 11 & $\mathrm{~T}$ \\
\hline Family: Polygonaceae & 1 & 6 & & & \\
\hline Fallopia convolvulus (L.) Á. Löve & & + & Arch & 10 & $\mathrm{~T}$ \\
\hline Fallopia dumetorum (L.) Á. Löve & & + & $\mathrm{Sp}$ & 7 & $\mathrm{~T}$ \\
\hline Polygonum aviculare $\mathrm{L}$. & & + & Ap & 11 & $\mathrm{~T}$ \\
\hline Rumex acetosella $\mathrm{L}$. & + & + & Ap & 3 & G \\
\hline Rumex acetosa $\mathrm{L}$. & & + & Ap & 2 & $\mathrm{H}$ \\
\hline Rumex obtusifolius L. & & + & Ap & 11 & $\mathrm{H}$ \\
\hline Family: Plumbaginaceae & 1 & 1 & & & \\
\hline $\begin{array}{l}\text { Armeria maritima (Mill.) Willd. subsp. } \\
\text { elongata(Hoffm.) Bonnier }\end{array}$ & + & + & Ap & 3 & $\mathrm{H}$ \\
\hline Family: Hypericaceae & 1 & 1 & & & \\
\hline Hypericum perforatum $\mathrm{L}$. & + & + & Ap & 3 & $\mathrm{H}$ \\
\hline Family: Cistaceae & 1 & 0 & & & \\
\hline $\begin{array}{l}\text { Helianthemum nummularium (L.) Mill. } \\
\text { subsp. obscurum (Čelak.) Holub }\end{array}$ & + & & $\mathrm{Sp}$ & 3 & $\mathrm{Ch}$ \\
\hline Family: Violaceae & 2 & 3 & & & \\
\hline Viola canina $\mathrm{L}$. & + & + & Ap & 5 & $\mathrm{H}$ \\
\hline Viola rupestris F.W. Schmidt & + & + & $\mathrm{Sp}$ & 3 & $\mathrm{H}$ \\
\hline Viola arvensis Murray & & + & Arch & 10 & $\mathrm{~T}$ \\
\hline Family: Brassicaceae & 3 & 6 & & & \\
\hline Berteroa incana (L.) DC. & + & + & Ap & 11 & $\mathrm{~T}$ \\
\hline Capsella bursa-pastoris L. & & + & Arch & 11 & $\mathrm{~T}$ \\
\hline Cardaminopsis arenosa (L.) Hayek & + & + & $\mathrm{Sp}$ & 2 & $\mathrm{H}$ \\
\hline Erophila verna (L.) Chevall. & & + & Ap & 3 & $\mathrm{~T}$ \\
\hline Erysimum cheiranthoides L. & & + & Ap & 11 & $\mathrm{~T}$ \\
\hline Lepidium ruderale $\mathrm{L}$. & + & & Arch & 11 & $\mathrm{~T}$ \\
\hline Sisymbrium altissimum $\mathrm{L}$. & & + & $\mathrm{Kn}$ & 11 & $\mathrm{~T}$ \\
\hline
\end{tabular}




\begin{tabular}{|c|c|c|c|c|c|}
\hline Family: Salicaceae & 0 & 3 & & & \\
\hline Populus $x$ canadensis Moench & & $+(\mathrm{a})$ & $\mathrm{Ef}$ & 12 & $\mathrm{~F}$ \\
\hline Populus nigra L. 'Italica' & & $+(\mathrm{a})$ & Ef & 12 & $\mathrm{~F}$ \\
\hline Salix acutifolia Willd. & & $+(b)$ & $\mathrm{Ef}$ & 12 & $\mathrm{~F}$ \\
\hline Family: Tiliaceae & 0 & 1 & & & \\
\hline Tilia cordata Mill. & & $+(b, c)$ & Ap & 9 & $\mathrm{~F}$ \\
\hline Family: Euphorbiaceae & 1 & 3 & & & \\
\hline Euphorbia cyparissias L. & + & + & Ap & 3 & $\mathrm{H}$ \\
\hline Euphorbia esula L. & & + & Ap & 3 & $\mathrm{H}$ \\
\hline Euphorbia peplus L. & & + & Arch & 10 & $\mathrm{~T}$ \\
\hline Family: Pyrolaceae & 0 & 1 & & & \\
\hline Orthilia secunda (L.) House & & + & $\mathrm{Sp}$ & 6 & $\mathrm{Ch}$ \\
\hline Family: Monotropaceae & 0 & 1 & & & \\
\hline Monotropa hypopitys L. & & + & $\mathrm{Sp}$ & 6 & G \\
\hline Family: Ericaceae & 2 & 2 & & & \\
\hline Calluna vulgaris (L.) Hull & + & + & $\mathrm{Sp}$ & 6 & $\mathrm{Ch}$ \\
\hline Arctostaphylos uva ursi (L.) Spring. & + & & $\mathrm{Sp}$ & 5 & $\mathrm{Ch}$ \\
\hline Vaccinium vitis-idaea $\mathrm{L}$. & & + & $\mathrm{Sp}$ & 6 & $\mathrm{Ch}$ \\
\hline Family: Rosaceae & 4 & 20 & & & \\
\hline Cerasus avium (L.) Moench & & $+(\mathrm{c})$ & $\mathrm{Kn}$ & 9 & $\mathrm{~F}$ \\
\hline Cerasus mahaleb (L.) Mill. & & $+(\mathrm{c})$ & Ef & 12 & $\mathrm{~F}$ \\
\hline Cerasus vulgaris Mill. & & $+(\mathrm{c})$ & Ef & 12 & $\mathrm{~F}$ \\
\hline $\begin{array}{l}\text { Cotoneaster divaricatus Rehder \& } \\
\text { E.H. Wilson }\end{array}$ & & $+(b)$ & Ef & 12 & $\mathrm{~F}$ \\
\hline Crataegus monogyna Jacq. & & $+(\mathrm{c})$ & Ap & 4 & $\mathrm{~F}$ \\
\hline Fragaria vesca $\mathrm{L}$. & + & + & $\mathrm{Sp}$ & 5 & $\mathrm{H}$ \\
\hline Fragaria viridis Duchesne & & + & Ap & 4 & $\mathrm{H}$ \\
\hline Malus domestica Borkh. & & $+(\mathrm{c})$ & Ef & 12 & $\mathrm{~F}$ \\
\hline Padus avium Mill. & & $+(\mathrm{c})$ & $\mathrm{Sp}$ & 8 & $\mathrm{~F}$ \\
\hline Padus serotina (Ehrh.) Borkh. & & $+(b, c)$ & $\mathrm{Kn}$ & 6 & $\mathrm{~F}$ \\
\hline Potentilla arenaria Borkh. & + & + & $\mathrm{Sp}$ & 3 & $\mathrm{H}$ \\
\hline Potentilla argentea $\mathrm{L}$. & + & + & Ap & 3 & $\mathrm{H}$ \\
\hline Pyrus communis L. & & $+(\mathrm{c})$ & Ap & 4 & $\mathrm{~F}$ \\
\hline Rosa canina $\mathrm{L}$. & $+(b)$ & $+(\mathrm{b})$ & Ap & 4 & $\mathrm{~F}$ \\
\hline Rosa rugosa Thunb. & & $+(b, c)$ & Ef & 12 & $\mathrm{~F}$ \\
\hline Rubus idaeus L. & & + & $\mathrm{Sp}$ & 5 & $\mathrm{Ch}$ \\
\hline Rubus plicatus Weihe \& Nees & & $+(b, c)$ & $\mathrm{Sp}$ & 6 & $\mathrm{Ch}$ \\
\hline Rubus saxatilis L. & & + & $\mathrm{Sp}$ & 6 & $\mathrm{H}$ \\
\hline Sorbus aucuparia L. emend. Hedl. & & $+(\mathrm{c})$ & $\mathrm{Sp}$ & 6 & $\mathrm{~F}$ \\
\hline Spiraea x pseudosalicifolia Silverside & & $+(b, c)$ & Ef & 12 & $\mathrm{~F}$ \\
\hline Family: Grossulariaceae & 0 & 1 & & & \\
\hline Ribes nigrum $\mathrm{L}$. & & $+(\mathrm{c})$ & $\mathrm{Sp}$ & 8 & $\mathrm{~F}$ \\
\hline
\end{tabular}




\begin{tabular}{|c|c|c|c|c|c|}
\hline Family: Crassulaceae & 3 & 2 & & & \\
\hline Sedum acre L. & + & + & Ap & 3 & $\mathrm{H}$ \\
\hline Sedum spurium M. Bieb. & & + & Ef & 12 & $\mathrm{H}$ \\
\hline Sedum sexangulare L. & + & & $\mathrm{Sp}$ & 3 & $\mathrm{H}$ \\
\hline Sempervivum tectorum $\mathrm{L}$. & + & & Ef & 12 & $\mathrm{H}$ \\
\hline Family: Fabaceae & 11 & 13 & & & \\
\hline Astragalus arenarius L. & + & + & Ap & 3 & G \\
\hline Genista tinctoria L. & + & & Ap & 6 & $\mathrm{Ch}$ \\
\hline Lotus corniculatus L. & + & & $\mathrm{Ap}$ & 2 & $\mathrm{H}$ \\
\hline Medicago falcata $\mathrm{L}$. & & + & $\mathrm{Ap}$ & 3 & $\mathrm{H}$ \\
\hline Medicago lupulina $\mathrm{L}$. & + & + & Ap & 11 & $\mathrm{H}$ \\
\hline Melilotus officinalis (L.) Pall. & & + & Ap & 11 & $\mathrm{~T}$ \\
\hline Robinia pseudacacia L. & & $+(\mathrm{a}, \mathrm{b})$ & $\mathrm{Kn}$ & 9 & $\mathrm{~F}$ \\
\hline Trifolium alpestre $\mathrm{L}$. & & + & $\mathrm{Ap}$ & 4 & $\mathrm{H}$ \\
\hline Trifolium arvense $\mathrm{L}$. & + & + & Ap & 3 & $\mathrm{~T}$ \\
\hline Trifolium campestre Schreb. & + & + & $\mathrm{Ap}$ & 3 & $\mathrm{~T}$ \\
\hline Trifolium hybridum $\mathrm{L}$. & + & & $\mathrm{Sp}$ & 2 & $\mathrm{H}$ \\
\hline Trifolium incarnatum L. & + & & Ef & 12 & $\mathrm{H}$ \\
\hline Trifolium pratense $\mathrm{L}$. & + & & $\mathrm{Ap}$ & 2 & $\mathrm{H}$ \\
\hline Trifolium repens $\mathrm{L}$. & + & & $\mathrm{Ap}$ & 11 & $\mathrm{H}$ \\
\hline Vicia angustifolia $\mathrm{L}$. & & + & Arch & 10 & $\mathrm{~T}$ \\
\hline Vicia cracca $\mathrm{L}$. & & + & Ap & 2 & G \\
\hline Vicia hirsuta (L.) Gray & & + & Arch & 10 & $\mathrm{~T}$ \\
\hline Vicia lathyroides L. & & + & $\mathrm{Sp}$ & 3 & $\mathrm{~T}$ \\
\hline Vicia tetrasperma (L.) Schreb. & + & + & Arch & 10 & $\mathrm{~T}$ \\
\hline Family: Rutaceae & 0 & 1 & & & \\
\hline Ptelea trifoliata $\mathrm{L}$. & & $+(\mathrm{b})$ & $\mathrm{Ef}$ & 12 & $\mathrm{~F}$ \\
\hline Family: Aceraceae & 0 & 3 & & & \\
\hline Acer negundo L. & & $+(\mathrm{b}, \mathrm{c})$ & $\mathrm{Kn}$ & 7 & $\mathrm{~F}$ \\
\hline Acer platanoides L. & & $+(\mathrm{c})$ & $\mathrm{Ap}$ & 9 & $\mathrm{~F}$ \\
\hline Acer pseudoplatanus L. & & $+(\mathrm{c})$ & Ap & 9 & $\mathrm{~F}$ \\
\hline Family: Geraniaceae & 3 & 3 & & & \\
\hline Erodium cicutarium (L.) L'Hér. & + & + & Ap & 3 & $\mathrm{~T}$ \\
\hline Geranium robertianum $\mathrm{L}$. & + & + & $\mathrm{Sp}$ & 9 & $\mathrm{~T}$ \\
\hline Geranium sanguineum $\mathrm{L}$. & + & + & $\mathrm{Sp}$ & 4 & $\mathrm{H}$ \\
\hline Family: Onagraceae & 1 & 4 & & & \\
\hline Chamaenerion angustifolium (L.) Scop. & & + & Ap & 5 & $\mathrm{H}$ \\
\hline Oenothera biennis L. & + & & Ap & 11 & $\mathrm{~T}$ \\
\hline Oenothera depressa Greene & & + & $\mathrm{Kn}$ & 11 & $\mathrm{~T}$ \\
\hline $\begin{array}{l}\text { Oenothera hoelscheri Renner ex } \\
\text { Rostański }\end{array}$ & & + & $\mathrm{Kn}$ & 11 & $\mathrm{~T}$ \\
\hline Oenothera rubricaulis Kleb. & & + & Ap & 11 & $\mathrm{~T}$ \\
\hline
\end{tabular}




\begin{tabular}{|c|c|c|c|c|c|}
\hline Family: Apiaceae & 1 & 3 & & & \\
\hline Peucedanum oreoselinum (L.) Moench & & + & $\mathrm{Sp}$ & 4 & $\mathrm{H}$ \\
\hline Pimpinella saxifraga $\mathrm{L}$. & + & + & Ap & 11 & $\mathrm{H}$ \\
\hline Torilis japonica (Houtt.) DC. & & + & Ap & 9 & $\mathrm{~T}$ \\
\hline Family: Rhamnaceae & 0 & 2 & & & \\
\hline Frangula alnus Mill. & & $+(\mathrm{c})$ & $\mathrm{Sp}$ & 8 & $\mathrm{~F}$ \\
\hline Rhamnus cathartica $\mathrm{L}$. & & $+(\mathrm{c})$ & $\mathrm{Sp}$ & 4 & $\mathrm{~F}$ \\
\hline Family: Oleaceae & 0 & 1 & & & \\
\hline Syringa vulgaris $\mathrm{L}$. & & $+(\mathrm{c})$ & $\mathrm{Kn}$ & 12 & $\mathrm{~F}$ \\
\hline Family: Rubiaceae & 1 & 5 & & & \\
\hline Galium album Mill. & & + & Ap & 3 & $\mathrm{H}$ \\
\hline Galium aparine $\mathrm{L}$. & & + & Ap & 9 & $\mathrm{~T}$ \\
\hline Galium boreale L. & & + & $\mathrm{Sp}$ & 2 & G \\
\hline Galium mollugo L. & & + & Ap & 2 & $\mathrm{H}$ \\
\hline Galium verum $\mathrm{L}$. & + & + & Ap & 3 & $\mathrm{H}$ \\
\hline Family: Caprifoliaceae & 0 & 1 & & & \\
\hline Sambucus nigra L. & & $+(\mathrm{c})$ & Ap & 9 & $\mathrm{~F}$ \\
\hline Family: Dipsacaceae & 1 & 0 & & & \\
\hline Scabiosa lucida Vill. & + & & $\mathrm{Sp}$ & 3 & $\mathrm{H}$ \\
\hline Family: Boraginaceae & 0 & 2 & & & \\
\hline Echium vulgare L. & & + & Ap & 11 & $\mathrm{~T}$ \\
\hline Symphytum officinale L. & & + & $\mathrm{Sp}$ & 2 & $\mathrm{H}$ \\
\hline Family: Solanace & 0 & 3 & & & \\
\hline Lycopersicum esculentum Mill. & & + & Ef & 12 & $\mathrm{~T}$ \\
\hline Solanum dulcamara L. & & + & $\mathrm{Sp}$ & 8 & $\mathrm{Ch}$ \\
\hline Solanum nigrum $\mathrm{L}$. & & + & Arch & 11 & $\mathrm{~T}$ \\
\hline Family: Scrophulariaceae & 6 & 8 & & & \\
\hline Euphrasia stricta D. Wolff ex J.F. Lehm. & + & & $\mathrm{Sp}$ & 5 & $\mathrm{~T}$ \\
\hline Linaria vulgaris Mill. & + & + & Ap & 11 & G \\
\hline Melampyrum pratense $\mathrm{L}$. & & + & $\mathrm{Sp}$ & 6 & $\mathrm{~T}$ \\
\hline Verbascum densiflorum Bertol. & . & + & Ap & 3 & $\mathrm{~T}$ \\
\hline Verbascum phlomoides $\mathrm{L}$. & & + & Ap & 3 & $\mathrm{~T}$ \\
\hline Verbascum thapsus L. & + & & Ap & 11 & $\mathrm{H}$ \\
\hline Veronica chamaedrys L. & + & + & Ap & 2 & $\mathrm{H}$ \\
\hline Veronica officinalis L. & + & + & Ap & 6 & $\mathrm{H}$ \\
\hline Veronica spicata $\mathrm{L}$. & + & & Ap & 3 & $\mathrm{H}$ \\
\hline Veronica sublobata M. A. Fisch. & & + & Ap & 6 & $\mathrm{~T}$ \\
\hline Veronica verna $\mathrm{L}$. & & + & Ap & 3 & $\mathrm{~T}$ \\
\hline Family: Plantaginaceae & 4 & 3 & & & \\
\hline Plantago arenaria Waldst. \& Kit. & + & & Ap & 3 & $\mathrm{H}$ \\
\hline Plantago intermedia Gilib. & & + & Ap & 1 & $\mathrm{H}$ \\
\hline Plantago lanceolata $\mathrm{L}$. & + & + & Ap & 2 & $\mathrm{H}$ \\
\hline
\end{tabular}




\begin{tabular}{|c|c|c|c|c|c|}
\hline Plantago major L. & + & + & Ap & 2 & $\mathrm{H}$ \\
\hline Plantago media L. & + & & Ap & 2 & $\mathrm{H}$ \\
\hline Family: Lamiaceae & 3 & 2 & & & \\
\hline Acinos arvensis (Lam.) Dandy & + & & Ap & 3 & $\mathrm{~T}$ \\
\hline Glechoma hederacea L. & & + & Ap & 9 & $\mathrm{H}$ \\
\hline Prunella vulgaris $\mathrm{L}$. & + & & $\mathrm{Sp}$ & 2 & $\mathrm{H}$ \\
\hline Thymus serpyllum L. emend. Fr. & + & + & Ap & 3 & $\mathrm{Ch}$ \\
\hline Family: Campanulaceae & 2 & 2 & & & \\
\hline Campanula rotundifolia $\mathrm{L}$. & + & + & Ap & 5 & $\mathrm{H}$ \\
\hline Jasione montana L. & + & + & Ap & 3 & $\mathrm{~T}$ \\
\hline Family: Asteraceae & 16 & 32 & & & \\
\hline Achillea millefolium $\mathrm{L}$. & + & + & Ap & 2 & G \\
\hline Artemisia campestris L. & + & + & Ap & 3 & $\mathrm{H}$ \\
\hline Artemisia vulgaris $\mathrm{L}$. & & + & Ap & 11 & $\mathrm{H}$ \\
\hline Carduus acanthoides L. & & + & Arch & 11 & $\mathrm{~T}$ \\
\hline Centaurea scabiosa L. & + & & Ap & 3 & $\mathrm{H}$ \\
\hline Centaurea stoebe L. & & + & Ap & 3 & $\mathrm{H}$ \\
\hline Chondrilla juncea $\mathrm{L}$. & & + & Ap & 3 & $\mathrm{H}$ \\
\hline Cichorium intybus $\mathrm{L}$. & + & & Arch & 11 & $\mathrm{H}$ \\
\hline Cirsium arvense (L.) Scop. & & + & Ap & 11 & G \\
\hline Cirsium vulgare (Savi) Ten. & & + & Ap & 11 & $\mathrm{~T}$ \\
\hline Conyza canadensis(L.) Cronquist & + & + & $\mathrm{Kn}$ & 11 & $\mathrm{~T}$ \\
\hline Crepis tectorum $\mathrm{L}$. & & + & Ap & 11 & $\mathrm{~T}$ \\
\hline Erigeron acris L. & + & + & Ap & 3 & $\mathrm{H}$ \\
\hline Erigeron annuus (L.) Pers. & + & + & $\mathrm{Kn}$ & 11 & $\mathrm{~T}$ \\
\hline Filago minima (Sm.) Pers. & + & & Ap & 3 & $\mathrm{~T}$ \\
\hline Galinsoga parviflora Cav. & & + & $\mathrm{Kn}$ & 10 & $\mathrm{~T}$ \\
\hline Helichrysum arenarium (L.) Moench & + & + & Ap & 3 & $\mathrm{H}$ \\
\hline Hieracium lachenalii C.C. Gmel. & & + & $\mathrm{Sp}$ & 6 & $\mathrm{H}$ \\
\hline Hieracium laevigatum Willd. & & + & $\mathrm{Sp}$ & 6 & $\mathrm{H}$ \\
\hline Hieracium pilosella $\mathrm{L}$. & + & + & Ap & 3 & $\mathrm{H}$ \\
\hline Hieracium umbellatum $\mathrm{L}$. & & + & Ap & 6 & $\mathrm{H}$ \\
\hline Hypochoeris radicata $\mathrm{L}$. & & + & Ap & 3 & $\mathrm{H}$ \\
\hline Lactuca serriola $\mathrm{L}$. & & + & Arch & 11 & $\mathrm{~T}$ \\
\hline Leontodon autumnalis $\mathrm{L}$. & + & + & Ap & 2 & $\mathrm{H}$ \\
\hline Leontodon taraxacoides (Vill.) Mérat & + & & Ap & 2 & $\mathrm{H}$ \\
\hline Mycelis muralis (L.) Dumort. & & + & $\mathrm{Sp}$ & 6 & $\mathrm{H}$ \\
\hline Scorzonera humilis L. & & + & $\mathrm{Sp}$ & 6 & $\mathrm{H}$ \\
\hline Senecio jacobaea $\mathrm{L}$. & & + & Ap & 3 & $\mathrm{H}$ \\
\hline Senecio sylvaticus L. & & + & Ap & 5 & $\mathrm{~T}$ \\
\hline Senecio vernalis Waldst.\& Kit. & + & + & $\mathrm{Kn}$ & 11 & $\mathrm{~T}$ \\
\hline Senecio viscosus L. & & + & Ap & 11 & $\mathrm{~T}$ \\
\hline
\end{tabular}




\begin{tabular}{|c|c|c|c|c|c|}
\hline Solidago virgaurea $\mathrm{L}$. & + & + & $\mathrm{Sp}$ & 6 & $\mathrm{H}$ \\
\hline Sonchus oleraceus L. & + & + & Arch & 10 & $\mathrm{~T}$ \\
\hline Taraxacum laevigatum (Willd.) DC. & & + & Ap & 2 & $\mathrm{H}$ \\
\hline Taraxacum officinale F. H. Wigg. & + & + & Ap & 2 & $\mathrm{H}$ \\
\hline Tragopogon floccosus Waldst.\& Kit. & & + & $\mathrm{Kn}$ & 11 & $\mathrm{H}$ \\
\hline Family: Convallariaceae & 0 & 2 & & & \\
\hline Convallaria majalis $\mathrm{L}$. & & + & $\mathrm{Sp}$ & 6 & G \\
\hline Polygnatum odoratum (Mill.) Druce & & + & $\mathrm{Sp}$ & 6 & G \\
\hline Family: Anthericaceae & 1 & 1 & & & \\
\hline Anthericum ramosum $\mathrm{L}$. & + & + & $\mathrm{Sp}$ & 4 & $\mathrm{H}$ \\
\hline Family: Asparaginaceae & 0 & 1 & & & \\
\hline Asparagus officinalis L. & & + & $\mathrm{Kn}$ & 3 & G \\
\hline Family: Iridaceae & 1 & 0 & & & \\
\hline Iris germanica L. & + & & Ef & 12 & G \\
\hline Family: Orchidaceae & 0 & 2 & & & \\
\hline Epipactis atrorubens (Hoffm.) Besser & & + & Ap & 6 & G \\
\hline Eipactis helleborine (L.) Crantz & & + & Ap & 9 & G \\
\hline Family: Juncaceae & 1 & 1 & & & \\
\hline Luzula campestris (L.) DC. & + & & $\mathrm{Sp}$ & 2 & $\mathrm{H}$ \\
\hline Luzula multiflora (Retz.) Lej. & & + & $\mathrm{Sp}$ & 5 & $\mathrm{H}$ \\
\hline Family: Cyperaceae & 3 & 5 & & & \\
\hline Carex arenaria $\mathrm{L}$. & + & + & Ap & 3 & G \\
\hline Carex caryophyllea Latourr. & & + & $\mathrm{Sp}$ & 1 & $\mathrm{H}$ \\
\hline Carex ericetorum Pollich & & + & Ap & 5 & $\mathrm{H}$ \\
\hline Carex hirta $\mathrm{L}$. & + & + & Ap & 11 & G \\
\hline Carex ligerica J. Gay & & + & Ap & 3 & G \\
\hline Carex praecox Schreb. & + & & Ap & 3 & $\mathrm{G}$ \\
\hline Family: Poaceae & 14 & 22 & & & \\
\hline Agrostis capillaris L. & + & + & Ap & 3 & $\mathrm{H}$ \\
\hline Agrostis vinealis Schreb. & & + & Ap & 3 & $\mathrm{H}$ \\
\hline $\begin{array}{l}\text { Arrhenatherum elatius (L.) P. Beauv. Ex } \\
\text { J. Presl \& C. Presl }\end{array}$ & & + & Ap & 2 & $\mathrm{H}$ \\
\hline Bromus inermis Leyss. & & + & Ap & 3 & G \\
\hline Bromus tectorum $\mathrm{L}$. & + & + & Arch & 11 & $\mathrm{~T}$ \\
\hline Briza media $\mathrm{L}$. & + & & $\mathrm{Sp}$ & 2 & $\mathrm{H}$ \\
\hline Calamagrosis arundinacea (L.) Roth & & + & $\mathrm{Sp}$ & 6 & $\mathrm{H}$ \\
\hline Calamagrostis epigejos (L.) Roth & + & + & Ap & 5 & $\mathrm{G}$ \\
\hline Corynephorus canescens (L.) P. Beauv. & + & + & Ap & 3 & $\mathrm{H}$ \\
\hline Dactylis glomerata L. & & + & Ap & 2 & $\mathrm{H}$ \\
\hline Danthonia decumbens DC. & + & & $\mathrm{Sp}$ & 5 & $\mathrm{H}$ \\
\hline Deschampsia flexuosa L. Trin. & & + & $\mathrm{Sp}$ & 6 & $\mathrm{H}$ \\
\hline $\begin{array}{l}\text { Digitaria ischaemum (Schreb.) } \\
\text { H. L. Mühl. }\end{array}$ & + & & Ap & 10 & $\mathrm{~T}$ \\
\hline
\end{tabular}




\begin{tabular}{|c|c|c|c|c|c|}
\hline Elymus repens (L.) Gould & & + & Ap & 11 & G \\
\hline Festuca ovina $\mathrm{L}$. & + & + & $\mathrm{Sp}$ & 6 & $\mathrm{H}$ \\
\hline Festuca pratensis Huds. & & + & Ap & 2 & $\mathrm{H}$ \\
\hline $\begin{array}{l}\text { Festuca psammophila (Hack. ex Čelak.) } \\
\text { Fritsch }\end{array}$ & & + & Ap & 3 & $\mathrm{H}$ \\
\hline Festuca rubra. L. & + & + & Ap & 2 & $\mathrm{H}$ \\
\hline Festuca trachyphylla (Hack.) Krajina & & + & Ap & 3 & $\mathrm{H}$ \\
\hline Koeleria macrantha (Ledeb.) Schult. & + & & $\mathrm{Sp}$ & 3 & $\mathrm{H}$ \\
\hline Koeleria glauca (Spring.) DC. & + & + & Ap & 3 & $\mathrm{H}$ \\
\hline Poa angustifolia $\mathrm{L}$. & + & + & $\mathrm{Sp}$ & 3 & $\mathrm{H}$ \\
\hline Poa annua $\mathrm{L}$. & + & + & Ap & 2 & $\mathrm{~T}$ \\
\hline Poa compressa $\mathrm{L}$. & & + & Ap & 3 & $\mathrm{H}$ \\
\hline Poa pratensis $\mathrm{L}$. & & + & Ap & 2 & $\mathrm{H}$ \\
\hline Setaria viridis (L.) P. Beauv. & + & + & Arch & 10 & $\mathrm{~T}$ \\
\hline
\end{tabular}

${ }^{1,2,3)}$ layers of vegetation: a - trees (canopy), $b$ - shrubs and undergrowth, $c$ - dwarf shrubs and herbaceous plants

${ }^{4)}$ denotations of geographical-historical, synaxonomical and Raunkiaer's life groups of species provided in part 3

The occurrence of these species was often dependent on the fact whether they manage to root sufficiently before the period of low rainfalls. Patches dominated by species of the aforementioned plants were adjacent to patches of Hieracium pilosella.

In 1948 the dune was deforested. This conclusion could be drawn from eight cut tree trunks marked on the vegetation map from that period. There were only few living trees. Only in the south-eastern part of the dune, several dozen of young specimens of Pinus sylvestris occurred, which most probably came from self-seeding. Three pine trees occurred in the northern part. They grew in one line. According to the detailed description provided by Anikiejówna and Gorska (1949), young specimens of Betula pendula were planted along the road running through the dune.

As far as shrubs are concerned, only two specimens of common juniper Juniperus communis and one specimen of Rosa canina occurred. 60 years ago the dune was covered with heaths in $20 \%$. They formed dense communities. Two species typical of this habitat, i.e. Calluna vulgaris and Arctostaphylos uva-ursi, occurred here in large numbers. In the nearest vicinity of heather patches, numerous clusters of lichens occurred. About half of the dune was overgrown with herbaceous-grass communities, whose diversity depends on the type and the extent of sand stabilization. It is also affected by inclination of the dune. Along the road, a grassland zone occurred. However, this vegetation was less characteristic of the dune. Among vascular plants, Achillea millefolium dominated here. In this place, plants occurred in a higher density as compared to the xerophilous meadow, where Thymus serpyllum was the dominant species. All the main types of vegetation patches, described in 1948, were presented on the map A (Fig. 9). Table 1 presents a list of species, which occurred on the Zadroże Dune in 1948. This table also provides the information on the affiliation of 102 species of vascular plants with 31 families, as well as on the species richness within these families.

At present, almost the entire area of the dune is overgrown with young pine forest stand, introduced on previously woodless grasslands and quick sand. Beneath the dense forest canopy, the grass herb layer is very scanty and occurs mainly in places with better insolation, along the forest peripheries. In 2009, the clearance of trees was carried out within the subsections $168 \mathrm{c}$ and $168 \mathrm{~d}$, what brought about the increased access of sunlight to the forest floor. At the same time, in many places logging and transport of wood caused some disturbance in the litter layer and deeper layers of the soil profile. Also piles of branches were left behind on the soil surface and on the herb layer. Due to thinning out the forest canopy, one should expect in the near future some floristic changes, which will make the discussed area resemble the typical open coniferous forests of the Bydgoszcz Forest.

In 2009 the number of lichen species increased by 19 species as compared to 1948. All 7 species, present on the species list published in 1949, were also recorded in 2009. At present, in the area of the Zadroże Dune, the occurrence of 26 lichen species was recorded, as well as 
1 species of lichenicolous fungi - Lichenoconium lecanorae, growing on apothecia of Lecanora conizaeoides.

The contemporary biota of lichens is represented in this area mainly by epigeic species from the genera Cladonia and Cetraria. Among the recorded taxa (Tab. 3), there are also epiphytic lichens occurring on the bark of Pinus sylvestris e.g. Hypogymnia physodes and Hypocenomyce scalaris, as well as epixylic lichens e.g. Placynthiella icmalea.

Lichens of the Zadroże Dune are common species in the whole country, typical for habitat conditions prevailing in the study area. Among them, 6 taxa are partially protected. These are: Cetraria aculeata, C. islandica, Cladonia arbuscula subsp. arbuscula, C. arbuscula subsp. mitis, C. ciliata, C. rangiferina (Regulation by the Minister of Environment dated July 9, 2004), and one of them - Cetraria islandica is also included on the Red List of lichens endangered in Poland, within the category VU - Vulnerable (Cieśliński et al. 2006).

At present, Cetraria islandica spreads in the city of Torun and its surroundings. In the 1980s this taxon was recorded at few locations (Wilkon-Michalska et al. 1988), and now it occurs in large numbers on psammophilous grasslands, heaths and forest areas of the city (Adamska 2008).

It is worthwhile to mention a taxon recorded in the study area - Baeomyces rufus, a species described as common in the whole country (cf. Nowak and Tobolewski 1975; Fałtynowicz 2003). In Torun and the immediate surroundings it was found, however, for the first time (cf. Wilkoń-Michalska et al. 1988; Adamska 2008).

A barren specimen of $B$. rufus was collected from sandy soil next to a forest road. This taxon was recorded only at one location. Most of the lichen species were recorded in the southern part of the Zadroże Dune, next to the cemetery. The vicinity of open space causes that more sunlight reaches the forest floor and thus it is more dry than inside the forest complex.

The latest studies on the flora of mosses and liverworts from 2009, proved the presence of 49 species of bryophytes, including 7 species of liverworts and 42 species of mosses (Tab. 3). Two species of liverworts i.e. Cephaloziella divaricata and Chiloscyphus polyanthos occurred in relatively large numbers. The remaining taxa were recorded only at few single locations. These are: Cephalozia pleniceps, C. hampeana, Lophocolea bidentata, Lophozia ventricosa and Ptilidium ciliare. The latter species is partially protected (Regulation by the Minister of Environment dated July 9, 2004). None of the aforementioned species of liverworts was recorded by Anikiejówna and Gorska (1949) in their studies, 60 years ago.

The present flora of mosses recorded in the herb layer of the studied area comprises 42 species. Among them, there are all species recorded by Anikiejówna and Górska.
Brachythecium (5 species) is the most numerous genera of the contemporary flora. Whereas, the following taxa were recorded on the Zadroże Dune in very small numbers and only at single locations: Abietinella hystricosa, Aloina rigida, Pohlia melanodon and Pseudocalliergon turgescens.

Species under strict protection are particularly noteworthy: Dicranum undulatum and Scorpidium scorpioides. These are partially protected taxa: Dicranum scoparium, Eurhynchium angustirete, Hylocomium splendens and Pleurozium schreberi.

The present vascular flora of the dune includes many species common with the flora described 60 years ago, their quantitative contribution, however, is much lower. Among such species there are for instance: Corynephorus canescens, Koeleria glauca, Thymus serpyllum, Carex praecox, Trifolium arvense, Potentilla argentea. Planting and subsequent development of pine with small, scattered admixture of European white birch, small-leaved lime, pedunculate oak, black locust and black cherry created the potential habitat for forest species. In the well developed moss layer (typical of coniferous forests), characteristic vascular plants, however, are scanty and cover a very small area (e.g. Dryopteris carthusiana, D. filix-mas, Vaccinium vitis-idaea, Convallaria majalis, Epipactis atrorubens, E. helleborine, Polygonatum odoratum, Monotropa hypopitys, Polypodium vulgare, Orthilia secunda). A track created in the eastern part of the dune, as well as the related penetration and littering along that track, contributed to the occurrence of not only xerophilous or oligotrophic ruderal plants, but in few places also eutrophic plants, such as Urtica dioica, Stellaria media, Artemisia vulgaris. Alien shrubs were artificially introduced or spontaneously spread through self-seeding - apart from the aforementioned black locust and black cherry, there occur also Syringa vulgaris, Ptelea trifoliata, Cotoneaster divaricatus, Spiraea sp. The total number of taxa almost doubled, reaching 199 species. The number of families, which comprise these vascular species increased from 31 in 1948 to 52 in 2009 (Tab. 4). There were only 66 species common in both compared floras (Tab. 4). As many as 37 species growing on the Zadroże Dune in 1948, were not recorded during the current research.

In 2009 the highest species richness occurred within the same families as 1948. In almost all cases, there are more species recorded in particular families at present than in 1949. In the family of Asteraceae, there were 16 species in 1948 and 32 species in 2009. Within the family of Poace$a e-14$ species were recorded 60 years ago, and 22 species in 2009. In the family of Fabaceae - 11 species were recorded during the first period of observations, and 13 species - during the second one. A significant increase in the number of species occurred in the family of Rosaceae - from 4 species in 1948 to 20 species in 2009. Alien species of ornamental shrubs have a considerable contribution 
in the latter period. In the past, they were planted on the cemetery adjacent to the Zadroże Dune. A minor increase was observed in the family of Brassicaceae - from 3 to 6 species, and in the family of Caryophyllaceae - from 7 to 11 species.

Among families, which were not represented during the first period of observations, but were recorded in 2009 , there are e.g. Salicaceae, Solanaceae and Orchidaceae. The former family was represented by alien species of trees - Populus nigra'Italica' and Populus x canadensis. The latter family was represented by orchids Epipactis atrorubens and E. helleborine, occurring on sandy soils.

The same number of species in both compared periods was recorded within the family Geraniaceae - i.e. 3 species. Also in the family of Ericaceae, the number of species has remained at the same level, i.e. 2 species. In 2009 , the presence of Arctostaphylos uva-ursi was not recorded, although this species occurred abundantly in 1948. Whereas in 2009, Vaccinium vitis-idaea was recorded, although it did not occur in 1948. Within the family of Plantaginaceae, there was a small decrease from 4 to 3 species, and in the family of Lamiaceae - from 3 to 2 species. In the case of two families, i.e. Cistaceae and Iridaceae, the number of species dropped from one to zero.

\subsubsection{Changes within geographical-historical groups, syngenetic groups of species, as well as spectra of life forms and the set of indices describing the extent of synanthropization of the flora}

Among 204 species of vascular plants building the contemporary flora of the Zadroże Dune, 160 species are recognized as native $(78.4 \%)$, including 50 species, which are non-synanthropic spontaneophytes and 110 - apophytes. In the group of 44 alien species, 13 archaeophytes were recorded $(6.6 \%$ of the total flora), 17 kenophytes $(8.6 \%)$ and 14 ergasiophytes (7\%).

Based on the vegetation description completed by Anikiejówna and Gorska (1949), it was calculated that among 102 species of vascular plants recorded in the studied area, as many as 88 species are native (i.e. $86.3 \%$ ). In the group of native species, apophytes dominated (60 species) over non-synanthropic spontaneophytes (28 species). Among 14 alien species, 7 archaeophytes $(6.9 \%)$ were distinguished, 4 kenophytes $(3.9 \%)$ and 3 ergasiophytes $(2.9 \%)$.

The percentage contribution of geographical-historical groups has undergone only some inconsiderable changes during the 60-year period (Tab. 5). Contribution proportions of non-synanthropic spontaneophytes and apophytes has changed slightly. The contribution of alien species, mainly kenophytes and ergasiophytes significantly increased.

In 1948 year, the flora of the Zadroże Dune was dominated by species characteristic of psammophilous and xerothermic grasslands (41 species, $40.2 \%$ ), as well as species of meadows and pastureland (17 species, 16.7\%), and ruderal communities ( 15 species, $14.7 \%$ ). Contemporarily, the contribution of species from psammophilous and xerothermic grasslands decreased to $24.5 \%$ (50 species), whereas meadow and pastureland species to $9.8 \%$ (20 species). The contribution of species from coniferous and deciduous forests evidently increased, as well as the count of species characteristic of other syntaxonomic groups (Tab. 6).

Most of the 37 species of vascular plants, which occurred on the Zadroże Dune at the end of the 1940s and which were not confirmed by the research performed in

Table 5. Comparison of the contribution of geographical-historical groups in the vascular flora of the Zadroże Dune

\begin{tabular}{|c|c|c|c|c|}
\hline \multirow{2}{*}{ Year and data source } & \multicolumn{2}{|c|}{$\begin{array}{c}\text { 2009 } \\
\text { (Anikiejówna \& Gorska 1949) }\end{array}$} & \multicolumn{2}{|c|}{ (Rutkowski \& Kaminski, this study) } \\
\cline { 2 - 5 } & $\begin{array}{c}\text { number } \\
\text { of species }\end{array}$ & $\begin{array}{c}\text { contribution } \\
\text { \% }\end{array}$ & $\begin{array}{c}\text { number } \\
\text { of species }\end{array}$ & $\begin{array}{c}\text { contribution } \\
\text { \% }\end{array}$ \\
\hline Sn & 28 & 27.5 & 50 & 24.5 \\
\hline Ap & 60 & 58.8 & 110 & 53.9 \\
\hline Arch & 7 & 6.9 & 13 & 6.4 \\
\hline Kn & 4 & 3.9 & 17 & 8.3 \\
\hline Ef & 3 & 2.9 & 14 & 6.9 \\
\hline Total & 102 & 100.0 & 204 & 100.0 \\
\hline
\end{tabular}

\footnotetext{
${ }^{1)}$ denotations of geographical-historical groups of species provided in part 3
} 
Table 6. Comparison of the contribution of syntaxonomic groups in the vascular flora of the Zadroże Dune

\begin{tabular}{|c|c|c|c|c|}
\hline \multirow{2}{*}{ Syntaxonomical group $^{1)}$ Year and data source } & \multicolumn{2}{|c|}{$\begin{array}{c}1948 \\
\text { (Anikiejówna \& Gorska 1949) }\end{array}$} & \multicolumn{2}{|c|}{$\begin{array}{c}2009 \\
\text { (Rutkowski \& Kamiński, this study) }\end{array}$} \\
\hline & number of species & contribution $\%$ & number of species & contribution $\%$ \\
\hline 1 & 1 & 1.0 & 1 & 0.5 \\
\hline 2 & 17 & 16.7 & 20 & 9.8 \\
\hline 3 & 41 & 40.2 & 50 & 24.5 \\
\hline 4 & 3 & 2.9 & 10 & 4.9 \\
\hline 5 & 7 & 6.9 & 9 & 4.4 \\
\hline 6 & 9 & 8.8 & 29 & 14.2 \\
\hline 7 & 0 & 0.0 & 2 & 1.0 \\
\hline 8 & 0 & 0.0 & 6 & 2.9 \\
\hline 9 & 1 & 1.0 & 19 & 9.3 \\
\hline 10 & 5 & 4.9 & 11 & 5.4 \\
\hline 11 & 15 & 14.7 & 33 & 16.2 \\
\hline 12 & 3 & 2.9 & 14 & 6.9 \\
\hline Total & 102 & 100.0 & 204 & 100.0 \\
\hline
\end{tabular}

${ }^{1)}$ denotations of synaxonomical groups of species provided in part 3

2009, are species characteristic of psammophilous and xerothermic grasslands (12 species), meadows and pastureland ( 8 species), as well as ruderal communities ( 5 species) and heaths ( 3 species). Afforestation of the area is the main reason behind these changes.

Not only the vegetation has changes from a grassland and heath type to a forest type, but also the contribution of life forms has changed (Tab. 7). When compared with the year 1948, the contribution of hemicryptophytes and low shrubs considerably decreased, whereas the contribution of trees and shrubs increased.

It was interesting to compare the indices of synanthropization of the flora from the Zadroże Dune, calculated based on the archival and contemporary data (Tab. 8). As compared with 1948, the increase of the following indices was observed: the total anthropophytism, kenophytism, modernization and fluctuation changes of the flora. These changes result from the increased number of alien species in the studied flora.

\section{Discussion and conclusions}

Afforestation of the dune is the main reason behind the floristic changes taking place during the last 60 years. Probably, the process of secondary forest reconstruction, as well as the process of species diversity changes, proceeded here in a similar way as in other areas, where dunes, heaths, psammophilous grasslands and xerothermic meadows were afforested. During the first several years after afforestation, the number of species probably decreased. This direction of transformations has persisted to this day in the central part of the reconstructed forest complex, where there are no any species at the forest floor. And thus, this kind of situation persists mainly in places, where an oligotrophic habitat endures and where there is a high density of forest canopy. Whereas, along the forest edges there are more favourable light conditions for species of the forest herb layer, and moreover there is considerable eutrophication of habitats, which results in the increased number of species, including also components alien to a forest community with more and more complicated structure. The increase of the species number follows the general trend, specified by Odum (1969), based on the comparisons of juvenile and mature phases. Apart from the stability and rhythmic- 
Table 7. Comparison of the contribution of life forms in the flora

\begin{tabular}{|c|c|c|c|c|}
\hline \multirow{2}{*}{ Year and data source } & \multicolumn{2}{|c|}{1948} & \multicolumn{2}{c|}{ 2009 } \\
Raunkiaer's life form ${ }^{1)}$ & (Anikiejówna \& Gorska 1949) & number of species & contribution \% \\
\hline number of species & contribution \% & 53 & 26.0 \\
\hline T & 9 & 23.5 & 19 & 9.3 \\
\hline H & 60 & 8.8 & 87 & 42.6 \\
\hline Ch & 5 & 58.8 & 7 & 3.4 \\
\hline F & 4 & 5.0 & 37 & 18.2 \\
\hline Ep & 0 & 3.9 & 1 & 0.5 \\
\hline Total & 102 & 0.0 & 204 & 100.0 \\
\hline
\end{tabular}

${ }^{1)}$ denotations of Raunkiaer's life groups of species provided in part 3

Table 8. Comparison of synanthropization indices for the vascular flora of the Zadroże Dune and other areas

\begin{tabular}{|c|c|c|c|c|}
\hline \multirow{2}{*}{ Index ${ }^{1)}$} & \multicolumn{2}{|c|}{ Dune Zadroże } & \multirow{2}{*}{$\begin{array}{c}\text { Forest reserve } \\
\text { „Płutowo” } \\
\text { (Rejewski 1974) }\end{array}$} & \multirow{2}{*}{$\begin{array}{c}\text { Gniezno Lake } \\
\text { District } \\
\text { (Chmiel 1993) }\end{array}$} \\
\hline & $\begin{array}{c}1948 \text { (Anikiejówna \& Gorska } \\
1949 \text { ) }\end{array}$ & $\begin{array}{l}2009 \text { (Rutkowski \& } \\
\text { Kamiński, this study) }\end{array}$ & & \\
\hline $\mathrm{WS}_{\mathrm{c}}$ & 72.55 & 75.49 & 48.65 & 59.5 \\
\hline $\mathrm{WAp}_{\mathrm{c}}$ & 58.82 & 57.89 & 40.00 & 36.0 \\
\hline WAp & 68.18 & 68.75 & 43.79 & 47.0 \\
\hline WAn $_{\mathrm{c}}$ & 13.73 & 21.57 & 8.65 & 23.5 \\
\hline $\mathrm{WAr}_{\mathrm{c}}$ & 6.86 & 6.37 & 3.78 & 9.2 \\
\hline $\mathrm{WKn}_{\mathrm{c}}$ & 3.92 & 8.33 & 3.24 & 7.2 \\
\hline WM & 36.36 & 56.67 & 46.15 & 44.1 \\
\hline WF & 2.94 & 6.86 & 1.62 & 7.1 \\
\hline
\end{tabular}

${ }^{1)}$ denotations of indices provided in part 3

ity of the climate, heterogeneity of the space, productivity, competition, predacity and thinning out, the time of the ecological system development is yet another factor, the increase of which causes the increase of the species diversity (Pianka 1981). The increased species number reflects also the increased fertility of forest habitats, observed during the last years and recently indicated by, for instance, Brzeziecki (1999) and Sokołowski (1991). As the cause of this phenomenon, they quote changes of environmental factors, including climatic factors, and the increase of atmospheric contamination, which intensifies the eutrophication of habitats. In the case of the Zadroże Dune, this increase takes place not only as a consequence of quite intensive contamination of the atmosphere by pollution coming from municipal services and industry of Torun (the city with the population of over 200 thousand inhabitants) and two other cities situated west of the dune, at a distance of ca. $35-50 \mathrm{~km}$ - Solec Kujawski (15 thousand inhabitants) and Bydgoszcz (almost 370 thousand inhabitants), but also as a consequence of direct penetration and littering the area by people, as well as the development of illegal dumping grounds in suburban forests.

Also the immediate proximity of the cemetery and the presence of the memorial commemorating the killed sol- 
diers, situated on the edge of the dune, are favourable to the encroachment of allien species. Alien species of ornamental plants introduced in these places, for instance Mahonia aquifolium or Cotoneaster divaricatus, spread in the forest complex. Forestry is yet another factor responsible for encroachment of alien species. Non-forest species enter during clearance and transport of wood, and this process facilitates the development of logging tracks and roads crossing the forest complexes. The presence of such elements in the forest landscape increases the penetration of the area by humans, as well as their influence on the species composition and the structure of spatial vegetation.

The influence of so many new factors brought about the fact that the number of vascular species significantly increased - from 102 to 204. The number of species also increased in the group of lichens and bryophytes, including both mosses and liverworts. It is necessary to emphasize, however, that changes of environmental factors were not the only cause for the increase of the species number, not in all the studied taxonomic groups. It is very probable that the significant increase in the number of lichen species on the Zadroże Dune, from 7 species in 1948 to 26 in 2009, does not result from changes in the species composition of the biota, but rather from the intensification of lichenological research carried out at present in this area.

The influence of silviculture and contamination of the atmosphere, as well as the influence of the busy communications route and housing estates situated next to it, is also revealed in the comparisons of synanthropization indices for the flora of the studied area with data from other regions. The indices calculated for the flora of the Zadroże Dune are higher when compared with the flora of the forest reserve „Płutowo” (Rejewski 1974), which can serve as a reference point due to a high degree of naturalness, but also when compared with the flora of anthropogenically highly transformed Lake District of Gniezno (Tab. 8). For instance in 1948, the index of total synanthropization for the Zadroże Dune had the value of 72.55 and in 2009 - 75.38; whereas when calculated for the forest reserve „Płutowo" and for the Lake District of Gniezno, it had the values of 48.65 and 59.50 respectively.

The transformation of the non-forest system into forest, triggered off changes in the spectrum of life forms, including particularly the increase of phanerophytes and the decrease of therophytes. It also brought about the disappearance of heaths, and thus the contribution of chamaephytes in the spectrum of life forms. Today, patches of heather persist on the biggest escarpments of the Zadroże Dune, in other words - in places where trees were not planted. It is characteristic that kinnikinnick Arctostaphylos uva-ursi completely withdrew from the afforested dune area. This is confirmed by the view of Hobbs (1984) and Ciosek (2000) that kinnikinnick is a pioneer species of heaths. It is defeated in the competition with heather, and it withdraws after pine cultivations are introduced on heathlands.

Afforestation of the dune brought about the increase of plant biomass accumulated on the dune and, at the same time, the increase of the carbon content in this biomass. Although only the main tree layer was included in the calculations, considerable reserves of the biomass of trees were recorded (expressed in cubic meters). The numerical values presented in this paper are burdened with a relatively high level of error. This is due to the fact that the results of measurements obtained for the sites of $400 \mathrm{~m}^{2}$ were expressed per total area of three larger forest fragments. It is worthwhile to repeat the measurements of the forest canopy in the near future and to calculate the reserves on the whole surface area of the Zadroże Dune covered with forest, i.e. 3.71 ha. Inclusion of the main forest canopy and the undergrowth in these measurements, would enable to determine more precisely the reserves of biomass and the carbon resources in this biomass, as well as to incorporate the ecological observations on the Zadroże Dune into the main stream of scientific studies performed with respect to prevention of the greenhouse effect.

In the 60-year history of land development and the process of vegetation changes on the Zadroże Dune, the approach was revealed to the significance of heaths in the landscape. They were usually perceived as wastelands, which should be afforested. Until recently this approach prevailed in the Polish society, but also among decisionmakers responsible for the development of nature space. Today, this view is being changed. Such changes are supported by the fact that heaths were included on the list of habitats, which require protection in the programme of the European Union Natura 2000. Some of them are worth preserving due to their cultural significance, but also due to the fact that they might become an interesting object of ecological and historical education. At the same time, they also commemorate the tragic past of the 2nd World War. For educational purposes, and also for preserving the high heterogeneity of the landscape and species diversity along the south-western outskirts of Torun, it is also worthwhile to preserve fragments of heathlands in the vicinity of the Zadroże Dune. The dune was already afforested, but there is also a possibility of preserving some of the interesting heath ecosystems in its vicinity.

Due to the research work contributed to the identification of the flora of the Zadroże Dune and its surrounding area, as well as the identification of the course of vegetation changes, it is worthwhile to continue the undertaken research and to assign the area as a permanent research site, incorporating it within the monitoring system of Torun and the Kujawy-Pomerania province. It is also worthwhile to create an educational trail on the Zadroże Dune and in its vicinity, as well as to install a plaque commemorating the fact that it was the first testing ground of team scientific 
studies performed by ecological naturalists from the Nicolaus Copernicus University, which was founded 65 years ago in Toruń.

\section{Acknowledgements}

The authors of this paper are grateful to the Forest Inspectorate of Cierpiszewo for the assistance in our studies on the history and the state of the forest from the Zadroże Dune, as well as to the students of Environment Protection, Ms Malwina Okrój and Mr Adam Rogowski, for their assistance in the preliminary identification of the range of certain plant communities and some representatives of the vascular flora of this nature object. The research presented in this paper was performed partly within the framework of the research grants by the Ministry of Science and Higher Education No. N N304 220835 and No. N N305 336834. We extend our acknowledgments to the Provincial Fund for Environmental Protection and Water Management in Torun for the financial support, which makes this publication possible.

\section{References}

Adamska E., 2008, Porosty Torunia na tle warunków siedliskowych miasta [Lichens of Torun in the habitat conditions of the city], Manuscript of the doctoral thesis, Department of Taxonomy and Plant Geography, Nicolaus Copernicus University, Torun.

Anikiejówna Cz. \& Gorska J., 1949, Stosunki florystyczne i fitosocjologiczne wydmy Zadroże [Floristic and phytosociological relationships of the Zadroże Dune, [in:] J. Prüffer (ed.) Z badań zespołowych wydmy Zadroże [Collective investigations on the Zadroże Dune near the city of Toruń], Studia Societatis Scentiarum Torunensis, Supplementum I: 27-36.

Brzeziecki B., 1999, Wzrost żyzności siedlisk leśnych: zjawisko pozorne czy rzeczywiste? [Increase of forest sites generosity - formal or real?], Sylwan 1999/11: 99-107.

Celka Z., 2004, Atlas rozmieszczenia roślin naczyniowych na grodziskach Wielkopolski [Distribution Atlas of Vascular Plants on the Earthworks of Wielkopolska], Prace Zakładu Taksonomii Roślin UAM w Poznaniu, nr 13, Bogucki Wydawnictwo Naukowe, Poznań.

Chmiel J., 1993, Flora roślin naczyniowych wschodniej części pojezierza gnieźnieńskiego i jej antropogeniczne przeobrażenia w wieku XIX i XX. Część 1 i 2 - Atlas rozmieszczenia roślin naczyniowych [Flora of vascular plants of the eastern part of the Gniezno Lake district and its transformation under the influence of man in the 19th and .Taksonomii Roślin UAM, No 1, Wyd. Sorus, Poznań.

Cieśliński S., Czyżewska K. \& Fabiszewski J., 2006, Red list of the lichens in Poland, [in:] Z. Mirek, K. Zarzycki, W. Wojewoda, Z. Szeląg (eds.), Red list of plants and fungi in Poland, W. Szafer Institute of Botany, Polish Academy of Sciences, Kraków: 71-89.

Ciosek M.T., 2000, Mącznica lekarska Arctostaphylos uva-ursi i wrzosowiska mącznicowe ArctostaphyloCallunetum w Polsce środkowowschodniej na tle ich zróżnicowania w Polsce [Bearberry, Arctostaphylos uva-ursi (L.) Spring., and bearberry moors, Arctostaphylo-Callunetum R. Tx. et Prsg 1949, in eastern central Poland in relation to their diversity in Poland], Rozprawa Naukowa Nr 65, WAP, Siedlce.

Czuraj M., 1990, Tablice miąższości kłód odziomkowych i drzew stojących [Volume tables for butt logs and standing trees], PWRiL, Warszawa.

Damsholt K., 2002, Illustrated Flora of Nordic Liverworts and Hornworts, Nord. Bryol. Soc., Lund.

Diederich P., Ertz D., Stapper N., Sérusiaux E. \& Ries C., 2009, The lichens and lichenicolous fungi of Belgium, Luxembourg and northern France, URL: http://www. lichenology.info

Fałtynowicz W., 2003, Krytyczna lista porostów i grzybów naporostowych Polski [The lichens, lichenicolous and allied fungi of Poland - an annotated checklist], W. Szafer Institute of Botany, Polish Academy of Sciences, Kraków.

Frahm J.P. \& Frey W., 1992, Moosflora, Mit 108 Abbildungen von J. Döring, 3 überarbeitete Auflage, Verlag Eugen Ulmer, Stuttgart.

Gajdówna E., 1949, Badania piasku z wydmy Zadroże [Investigations of sand from the dune Zadroże], [in:] J. Prüffer (ed.) Z badań zespołowych wydmy Zadroże [Collective investigations on the Zadroże Dune near the city of Toruń], Studia Societatis Scentiarum Torunensis, Supplementum I: 11-14.

Galon R., 1958, Z problematyki wydm śródlądowych w Polsce [Sur les dunes continentales en Polotne], [in:] R. Galon (ed.) Wydmy śródlądowe Polski, część pierwsza [Les dunes continentales en Pologne, premier partie], PWN, Warszawa: 13-31.

Hobbs R. J., 1984, Possible chemical interactions among heathland plants, Oikos 43(1): 23-29.

Jackowiak B., 1990, Antropogeniczne przemiany flory roślin naczyniowych Poznania [Anthropogenic changes of the flora of vascular plants of Poznań], Wyd. Nauk. UAM, Seria Biologica 42.

Kobendza J., \& Kobendza R., 1958, Rozwiewane wydmy Puszczy Kampinoskiej [Les dunes éparpillées de la Forêt de Kampinos], [in:] R. Galon (ed.) Wydmy śródlądowe Polski, część pierwsza [Les dunes conti- 
nentales en Pologne, premier partie], PWN, Warszawa: 95-170.

Kornaś J., 1968, Geograficzno-historyczna klasyfikacja roślin synantropijnych[Geographical-historical classification of synanthropic plants], [in:] Synantropizacja szaty roślinnej - I Neofityzm i apofityzm - Materiały sympozjum w Nowogrodzie, [Synanthropization of plant cover - I Neophytizm and apophytizm - Materials of symposium in Nowogród], Materiały Zakładu Fitosocjologii Stosowanej UW 25: 33 - 41, Warszawa - Białowieża.

Krzysik F., 1978, Nauka o drewnie [Wood science], Państwowe Wyd. Naukowe, Warszawa.

Łosiński J. \& Mikulski J., 1949, Obserwacje mikroklimatyczne na wydmie Zadroże [Microclimatic observations on the dune Zadroże], [in:] J. Prüffer (ed.) Z badań zespołowych wydmy Zadroże [Collective investigations on the Zadroże Dune near the city of Toruń], Studia Societatis Scentiarum Torunensis, Supplementum I: $15-26$

Mapa topograficzna z 1909 r., skala 1: 25 000, arkusz 1583 Podgorz [Topographic map from 1909 at the scale of 1:25,000, sheet 1583 Podgorz], Preuß. Landesaufnahme.

Mapa topograficzna z 1934 r., skala 1:25 000, arkusz 3077 Podgorz [Topographic map from 1934, the scale 1:25,000, sheet 3077 Podgorz], Reichsamt für Landesaufnahme.

Mapa topograficzna z 1948 r., skala 1:50 000, wiersz 37, kolumna 27 - Ciechocinek-A [Topographic map from 1948, the scale 1:50,000, row 37, column $27-$ Ciechocinek-A], Sztab Generalny [the General Staff], Warszawa.

Mapa topograficzna z 1963 r., skala 1:25 000, arkusz nr 8 [Topographic map from 1963, scale 1:25,000, sheet no. 8], Zarząd Topograficzny Sztabu Generalnego WP [the Topographic Board of the General Staff of the Polish Armed Forces], Warszawa.

Mapa topograficzna z 1971 r., skala 1:25 000, arkusz 355.32 Toruń [Topographic map from 1971, scale 1:25,000, sheet 355.32 Toruń], GUGiK, Warszawa.

Mapa topograficzna z 1987 r., skala 1:25 000, arkusz N34-110-A-a Podgórz [Topographic map from 1987, scale 1:25,000, sheet N-34-110-A-a Podgórz], Sztab Generalny WP [the General Staff of the Polish Armed Forces], Warszawa.

Mapa topograficzna z 2000 r., skala 1:10 000, arkusz N34-110-A-a-1 Mała Nieszawka [Topographic map from 2000, scale 1:10,000, sheet N-34-110-A-a-1 Mała Nieszawka], Główny Geodeta Kraju [Surveyor General of Poland], Warszawa.

Matuszkiewicz W., 2001, Przewodnik do oznaczania zbiorowisk roślinnych Polski [A guide for identification of plant communities in Poland], Vademecum Geobotanicum, Wydawnictwo Naukowe PWN, Warszawa.

Mirek Z., 1981, Problemy klasyfikacji roślin synantropijnych [Problems of classification of synanthropic plants], Wiad. Bot. 25(1): 45 - 54.

Mirek Z., Piękoś-Mirkowa H., Zając A. \& Zając M., 2002, Krytyczna lista roślin naczyniowych Polski [Flowering plants and pteridophytes of Poland, A checklist], W. Szafer Institute of Botany, Polish Academy of Sciences, Kraków.

Nowak J. \& Tobolewski Z., 1975, Porosty Polskie, PWN, Warszawa.

Ochyra R., Żarnowiec J. \& Bednarek-Ochyra H., 2003, Census catalogue of Polish mosses, Polish Academy of Sciences, Institute of Botany, Kraków.

Odum E. P., 1969, The strategy of ecosystem development, Science 164: 262-270.

Okołowicz W., 1949, Opis geograficzny wydmy Zadroże [The geographical description of the dune Zadroże], [in:] J. Prüffer (ed.) Z badań zespołowych wydmy Zadroże [Collective investigations concerning the Zadroże dune near Toruń], Studia Societaris Scientiarum Torunensis, Supplementum I: 3-10.

Operat glebowo-siedliskowy. Nadleśnictwo Cierpiszewo, Obręb Cierpiszewo, 2000, Regionalna Dyrekcja Lasów Państwowych w Toruniu [Survey on soils and habitats, the Forest Division of Cierpiszewo, the District of Cierpiszewo, 2000, Regional Administration of State Forests in Toruń], Toruń.

Orange A., James P. W. \& White F. J., 2001, Microchemical methods for the identification of lichens, British Lichen Society, London.

Pianka E. R., 1981, Ekologia ewolucyjna [Evolutionary ecology], PWN, Warszawa.

Plan urządzenia lasu. Opis ogólny, Nadleśnictwo Cierpiszewo, Obręby: Cierpiszewo-Zawiszyn, 2008-2017, Tom 1, Cz. 1, Regionalna Dyrekcja Lasów Państwowych w Toruniu [Forest Management Plan. General description, the Forest Division of Cierpiszewo, Districts of Cierpiszewo and Zawiszyn, 2008-2017, Volume 1, Part 1, Regional Administration of State Forests in Toruń], Torun.

Purvis O. W., Coppins B. J., Hawksworth D. L., James P. W. \& Moore, D. M., 1992, The lichen flora of Great Britain and Ireland. Natural History Museum \& British Lichen Society, London.

Rejewski M., 1974, Roślinność rezerwatu leśnego "Parowy Płutowskie" [Vegetation des Waldreservats „Parowy Płutowskie"], Acta Univ. Nicolai. Copernici 33, Biologia 16: $99-124$.

Rejment Grochowska I., 1971, Bryophyta II: Hepaticae Wątrobowce, Flora słodkowodna Polski Tom 17 [Bryophyta II: Hepaticae - Liverworts, Freshwater flora of 
Poland, Volume 17], Instytut Botaniki PAN, K. Starmach, J. Siemińska (eds.), Wyd. PWN, Kraków.

Rozporządzenie Ministra Środowiska z dnia 9 lipca 2004 r. w sprawie dziko występujących grzybów objętych ochroną, Dz. U. Nr 168, poz. 1765 [Regulation of the Minister of Environment dated July 9, 2004 on growing wild, legally protected fungi, Dz. U. (Journal of Laws) No. 168, item 1765].

Santesson R., Moberg R., Nordin A., Tönsberg T. \& Vitikainen O., 2004, Lichen-forming and lichenicolous fungi of Fennoscandia, Museum of Evolution, Uppsala University.

Sokołowski A., 1991, Changes in species composition of a mixed Scots Pine - Noway Spruce forest at the Augustów Forest during the period 1964 - 1987, Folia Forestalia Polonica, Series A - Forestry 33: 5-24.

Szafran B., 1957, Bryophyta, Mchy (Musci) Tom I, Flora Polska [Bryophyta, Mosses (Musci) Volume I, Flora of Poland], Polska Akademia Nauk, Instytut Botaniki, Wyd. PWN, Warszawa.

Szafran B., 1961, Rośliny zarodnikowe Polski i ziem ościennych: Mchy (Musci), Tom II [Cryptogamic plants of Poland and neighbouring lands: Mosses (Musci), Volume II], Wyd. PWN, Warszawa.
Szafran B., 1963, Bryophyta I: Musci - Mchy. Flora słodkowodna Polski Tom 16 [Bryophyta I: Musci Mosses. Freshwater flora of Poland, Volume 16], Wyd. Instytut Botaniki PAN, K. Starmach (ed.), Kraków.

Szweykowski J., 2006, An annotated checklist of polish liverworts \& hornworts, W. Szafer Institute of Botany, Polish Academy of Sciences, Kraków.

Szymkiewicz B., 2001, Tablice zasobów i przyrostu drzewostanów ważniejszych gatunków drzew leśnych [Yield and stand increment tables for major forest tree species], Państwowe Wydawnictwo Rolnicze i Leśne, Warszawa.

Wilkoń-Michalska J., Glazik N. \& Kalińska A., 1988, Porosty miasta Torunia [The lichens of Toruń town], Acta Univ. Nicolai Copernici 63, Biologia 29: 209-253.

Wirth V., 1995, Die Flechten Baden-Württembergs, 1-2, Eugen Ulmer, Stuttgart.

Wojskowa mapa topograficzna z 2003 r., skala 1:25 000, arkusz N-34-110-A-A,B Toruń - 2 [Poland military city maps from 2003, scale 1:25,000, sheet N-34110-A-A,B Toruń - 2], Sztab Generalny WP [the General Staff of the Polish Armed Forces], Warszawa. 